\title{
Analysis and Interpretation of Water-Quality Trends in Major U.S. Rivers, 1974-81
}

\section{United States Geological Survey Water-Supply Paper 2307}

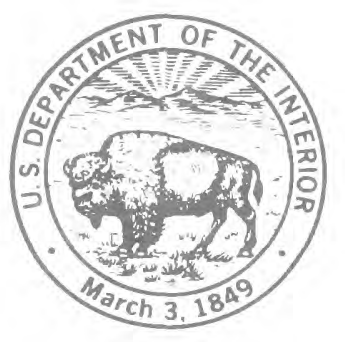




\section{Analysis and Interpretation of Water-Quality Trends in Major U.S. Rivers, $1974-81$}

By RICHARD A. SMITH, RICHARD B. ALEXANDER, and M. GORDON WOLMAN 


\title{
DEPARTMENT OF THE INTERIOR DONALD PAUL HODEL, Secretary
}

\author{
U.S. GEOLOGICAL SURVEY \\ Dallas L. Peck, Director
}

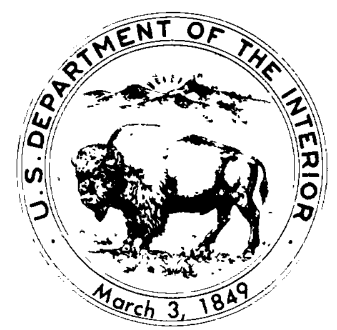

UNITED STATES GOVERNMENT PRINTING OFFICE: 1987

For sale by the Superintendent of Documents, U.S. Government Printing Office,

Washington, DC 20402

Library of Congress Cataloging in Publication Data

Smith, Richard A.

Analysis and interpretation of water-quality trends in major U.S. rivers, 1974-81.

(U.S. Geological Survey water-supply paper ; 2307)

Bibliography: $p$.

Supt. of Docs. no.: । 19.13;2307

1. Water quality-United States. 2. Water chemistry. 3. Rivers-United

States. I. Alexander, Richard B. II. Wolman, M. Gordon (Markley

Gordon), 1924- . III. Title. IV. Series: Geological Survey

water-supply paper ; 2307.

TD223.S65 $1987 \quad 363.7$ '3942'0973 86-600213 


\title{
CONTENTS
}

\author{
Abstract 1 \\ Introduction 1 \\ Methods and scope 2 \\ Trend analysis and interpretation $\mathbf{5}$ \\ Chloride $\mathbf{5}$ \\ Sulfate 8 \\ Nitrate 9 \\ Alkalinity and base cations 10 \\ $\mathrm{pH} \quad 12$ \\ Suspended sediment 13 \\ Total phosphorus 13 \\ Dissolved-oxygen deficit 14 \\ Fecal coliform and fecal streptococcus bacteria $\quad 16$ \\ Lead 17 \\ Arsenic 19 \\ Cadmium 20 \\ Other trace metals 20 \\ Conclusions 21 \\ References cited 22
}

\section{FIGURES}

1-7. Maps showing:

1. Locations of sampling stations in the National Stream Quality Accounting Network and the National Water Quality Surveillance System in the conterminous United States 3

2. Change in surface-coal production in NASQAN drainage basins, 1974-81 7

3. Trends in flow-adjusted concentrations of chloride at NASQAN stations, 1974-81 8

4. Trends in flow-adjusted concentrations of sulfate at NASQAN stations, 1974-81 9

5. Trends in flow-adjusted concentrations of nitrate at NASQAN and NWQSS stations, 1974-81 10

6. Trends in flow-adjusted concentrations of alkalinity at NASQAN stations, 1974-81 11

7. Trends in flow-adjusted concentrations of suspended sediment at NASQAN stations, 1974-81 12

8. Graph showing comparison of the distribution of point-source biochemical oxygen demand loads for river reaches in cataloging units containing combined network stations with the similar distribution for all cataloging units 16

9, 10. Maps showing:

9. Trends in flow-adjusted concentrations of fecal streptococcus bacteria at NASQAN and NWQSS stations, 
1974-81 17

10. Trends in dissolved lead at NASQAN stations, 1974-81 18

11. Graph showing changes in mean rates of gasoline-lead consumption and stream-lead yield in NASQAN drainage basins 18

12, 13. Maps showing:

12. Trends in dissolved arsenic at NASQAN stations, 1974-81 19

13. Trends in dissolved cadmium at NASQAN stations, 1974-81 21

\section{TABLES}

1. Statistical summary of water-quality conditions and trends, 1974-81, at NASQAN and NWQSS sampling stations in the conterminous United

States 4

2. Ancillary data used in the interpretation of NASQAN and NWQSS trend results 6

3. Tests of association between trends in dissolved-oxygen deficit and various measures of municipal biochemical oxygen demand loads upstream from combined network stations 14 


\title{
Analysis and Interpretation of Water-Quality Trends in Major U.S. Rivers, 1974-81
}

\author{
By Richard A. Smith, Richard B. Alexander, and M. Gordon Wolman
}

\begin{abstract}
Water-quality records from two nationwide sampling networks are now of sufficient length to permit nationally consistent analysis of long-term water-quality trends at more than 300 locations on major U.S. rivers. Observed trends in 24 water-quality measures for the period 1974-81 provide evidence of both improvement and deterioration in stream quality during a time of major changes in atmospheric and terrestrial influences on surface waters. Particularly noteworthy are widespread decreases in lead and fecal bacteria concentrations and widespread increases in nitrate, arsenic, and cadmium concentrations. Changes in municipal waste treatment, leaded-gasoline consumption, highway-salt use, and nitrogen-fertilizer application, and regionally variable trends in coal production and combustion during the period, appear to be reflected in water-quality changes. There is evidence that atmospheric deposition of a variety of substances has played a surprisingly large role in water-quality changes.
\end{abstract}

\section{INTRODUCTION}

More than a decade ago, several investigators (Ackerman and others, 1970; Wolman, 1971) sought to describe long-term trends in water quality of the Nation's rivers and found that a major difficulty in doing so was the lack of continuous and consistent water-quality records. Records then available for describing regional or nationwide trends had to be assembled from a large number of sources, many of which were discontinuous in time or had relatively limited constituent coverage reflecting a concern with local water-quality problems. Moreover, differences in sampling and laboratory methods and in the criteria for siting stations made identification of regional trends very difficult.

In the years immediately following these studies, several Federal programs for nationally consistent water-quality data collection were established in response to increased interest in water-quality trends. The most comprehensive of these was the
U.S. Geological Survey's National Stream Quality Accounting Network (NASQAN), which in 1972 established monthly sampling for some 30 constituents at stations located near the outlets of major drainage basins so as to collectively monitor a large fraction of total U.S. runoff (Briggs, 1978). The location of NASQAN stations was not based on the presence or absence of pollution sources in the vicinity of the stations, but a focus on large rivers has resulted in a moderate bias toward higher pollution loads. The number of stations in the network has increased from 50 in 1972 to 501 in 1985 with the gradual addition of stations higher in the drainage of the major interior basins as well as stations in small coastal basins. Costs of the program since its inception have totaled about $\$ 45$ million. A second water-quality monitoring program, the National Stream Quality Surveillance System (NWQSS), was initiated by the U.S. Environmental Protection Agency (EPA; 1976) in 1974 to help track progress in pollution control efforts. Sampling and laboratory analyses at most NWQSS sites were performed by the U.S. Geological Survey for the EPA using procedures identical to those used in the NASQAN program. The 188-station sampling program focused on dissolved oxygen and nutrient levels in rivers and included fewer constituents than that of NASQAN. Stations were located both upstream and downstream from selected urban and agricultural areas, and on somewhat smaller streams than NASQAN stations. Like NASQAN, however, the primary objective of NWQSS was trend identification. Total cost for the program through 1981 , when sampling was discontinued, was about $\$ 10$ million.

Since their establishment, the nationwide fixed-station networks have provided data for several general summaries of water-quality conditions (Briggs and Ficke, 1977; Council on Environmental Quality, 1982; U.S. Geological Survey, 1983; Peters, 1984 ) but have been used to only a limited extent in 
interpretive studies of long-term trends (Conservation Foundation, 1984; Smith and Alexander, 1984; Gilliom and others, 1985). There have been several impediments to such studies. First, it has taken time to collect records long enough for worthwhile trend analysis. Not until 1975 did NASQAN include as many as 300 stations, so that only recently has the data base been sufficient to permit a truly nationwide study of trends. Second, specific techniques for dealing with the commonly encountered statistical problems of water-quality trend detection, including seasonality, flow dependence, and the occurrence of values reported as "less than" the laboratory detection limit, have only recently become available (Hirsch and others, 1982; Smith and others, 1982). Finally, interpretation of possible causes of waterquality trends requires ancillary information on land use, pollution sources, and other environmental factors. Nationally consistent data bases for a variety of environmental variables have been established within the past decade and only recently have become large enough and complete enough to use in the interpretation of water-quality trends. Partly because of the difficulties in detecting and interpreting trends in fixed-station data, recent nationwide assessments of water-quality trends have taken the form of surveys (ASIWPCA, 1984, 1985; Judy and others, 1984) of local environmental and naturalresource officials concerning their knowledge of and opinions on changes in water quality. While the advantage of such surveys is their capacity for integrating chemical as well as ecological information into a concise summary of conditions, the disadvantage is a loss of detail and objectivity.

In this paper, we present an analysis of trends in stream-water quality based on data from the NASQAN and NWQSS networks, which collectively provide the largest available set of nationally consistent data on water-quality conditions in U.S. rivers. The study period was October 1974 through October 1981, the approximate limits of operation of NWQSS. During this period, major changes occurred in several factors influencing water quality in the United States, including large reductions in point-source pollution loads and regionally variable changes in nonpoint-source influences, both terrestrial and atmospheric. We begin by presenting a summary of statistically defined trends for 24 constituents, giving a brief description of the geographic pattern of trends in each. We then investigate possible explanations for the observed trend patterns using data describing changes in basin conditions during the study period.

\section{METHODS AND SCOPE}

Two hundred ninety-four NASQAN stations and 94 NWQSS stations (fig. 1) are collectively referred to as "combined network" stations. Owing to the more limited constituent coverage at NWQSS stations, results are presented for 6 constituents at combined network stations and for 18 constituents at NASQAN stations only (table 1). Data for waterquality constituents were collected biweekly at NWQSS stations and were averaged to produce monthly time series. Data for common constituents were collected monthly, and for trace metals, quarterly, at NASQAN stations. Sampling and laboratory procedures (Guy and Norman, 1970; Skougstad and others, 1979) were the same for all stations throughout the study period. Statistical procedures applied to these water-quality records have been previously described in detail (Hirsch and others, 1982; Smith and others, 1982; Smith and Alexander, $1983 \mathrm{~b})$. Trend analyses were conducted using the Seasonal Kendall test (Hirsch and others, 1982; Smith and others, 1982), which is intended for monthly water-quality time series with potentially large seasonal variability. Because the test is nonparametric, outliers, missing values, or values defined as "less than" the laboratory detection limit (see table 1) present no computational or theoretical problem in its application. "Trend" is defined as monotonic change in time, occurring as either an abrupt or a gradual change in concentration. Trends were considered statistically significant for $p<0.10$ ( $p$ is the probability that an apparent trend resulted from a chance arrangement of the data rather than from an actual change in concentration). Records for the 15 "common" constituents were flow-adjusted (Hirsch and others, 1982; Smith and others, 1982; Smith and Alexander, 1983b) prior to trend testing in an attempt to eliminate streamflow variation as either a cause of trend or a confounding influence in its detection. Owing to the presence of "less than" values, trace element records were not flow-adjusted prior to trend testing. For the same reason, the magnitude of the trend slope, which is estimated separately from the trend test (Smith and others, 1982), could not be reliably determined for trace constituents.

Evaluation of the possible influence of streamflow variation on trends in trace element concentrations was undertaken by testing the statistical association between trace element trends and trends in streamflow measurements made at the time of water-quality sampling. Contingency tables were constructed as three-by-three arrays (increases, decreases, no trends) and tested for chi 


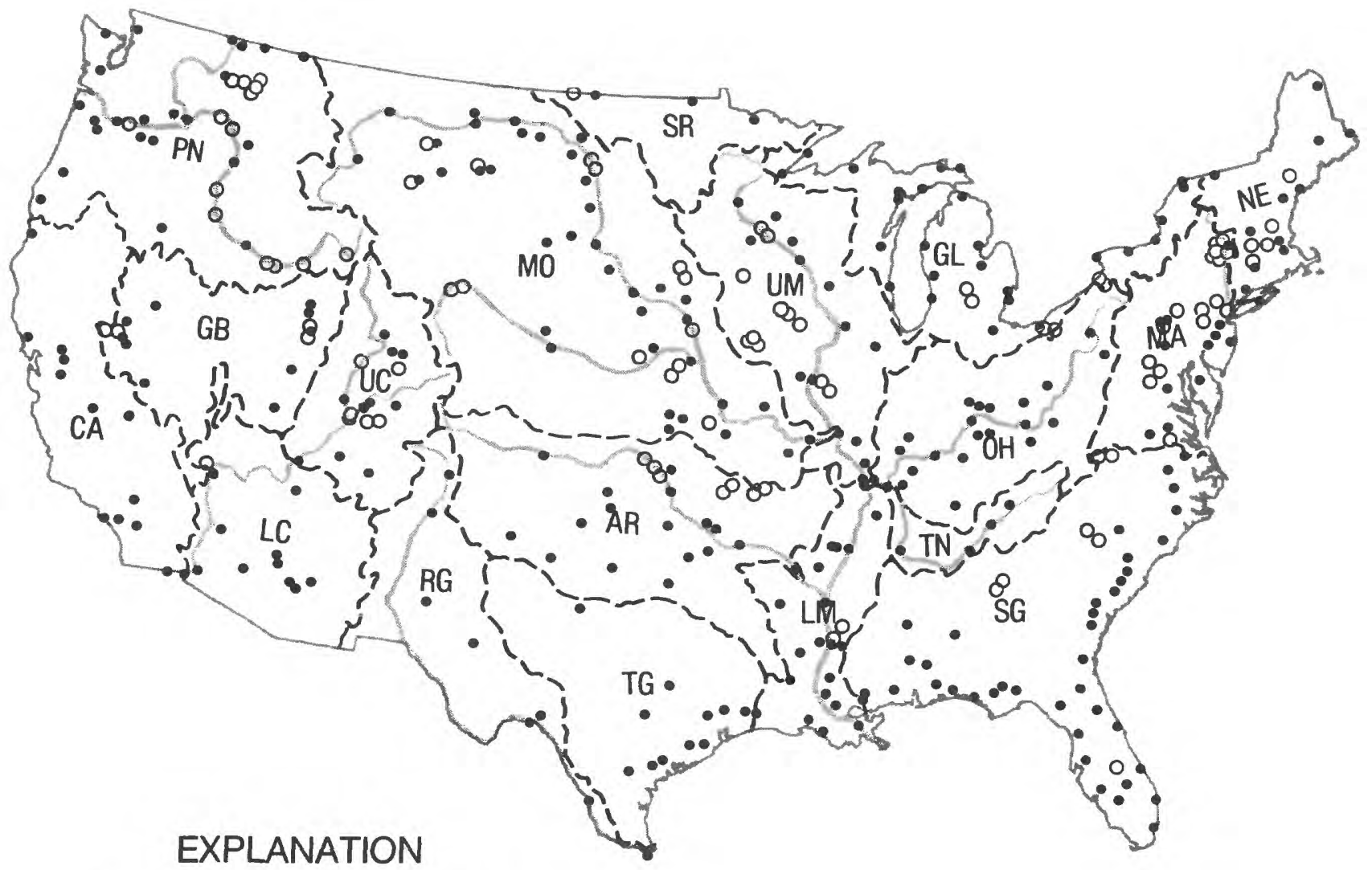

-- Boundary of Regional Drainage BasinLetters Are Abbreviation for Drainage

Basin Name (See Figure Caption)

\section{Largest U.S Rivers}

- Location of Sampling Station in the National Stream Quality Accounting Network

- Location of Sampling Station in the National Water Quality Surveillance System

Figure 1. Locations of sampling stations in the National Stream Quality Accounting Network and the National Water Quality Surveillance System in the conterminous United States. Regional drainage basins are abbreviated as follows: New England, NE; Mid-Atlantic, MA; Southeast-Gulf, SG; Tennessee, TN; Ohio, OH; Great Lakes, GL; Upper Mississippi, UM; Lower Mississippi, LM; Texas-Gulf, TG; Arkansas-Red, AR; Missouri, MO; Souris-Red-Rainy, SR; Rio Grande, RG; Lower Colorado, LC; Upper Colorado, UC; Great Basin, GB; California, CA; Pacific Northwest, PN. Most NASQAN stations lie on tributaries to the major rivers of the basins, and most NWQSS stations lie on still smaller rivers in the vicinity of selected urban and agricultural areas.

square significance (Conover, 1980). Trends in three constituents-iron, manganese, and zinc-were moderately to highly associated with trends in flow. Similar contingency tables constructed to test the association between streamflow trends and trends in common constituents served as a check on the effectiveness of the flow-adjustment procedure. Trends in 3 of the 15 common constituents (sulfate, sodium, and $\mathrm{pH}$ ) showed a weak association to streamflow trends, indicating that flow adjustment was gener- ally successful in correcting for flow dependence in the data. Contingency tables for sulfate, sodium, and $\mathrm{pH}$ indicated that streamflow variation affected trend results for those constituents at fewer than 10 percent of the stations.

In addition to describing regional trend patterns, we consider preliminary hypotheses for causes of the observed water-quality changes in cases where single factors may have significantly affected the national distribution of trends. We 


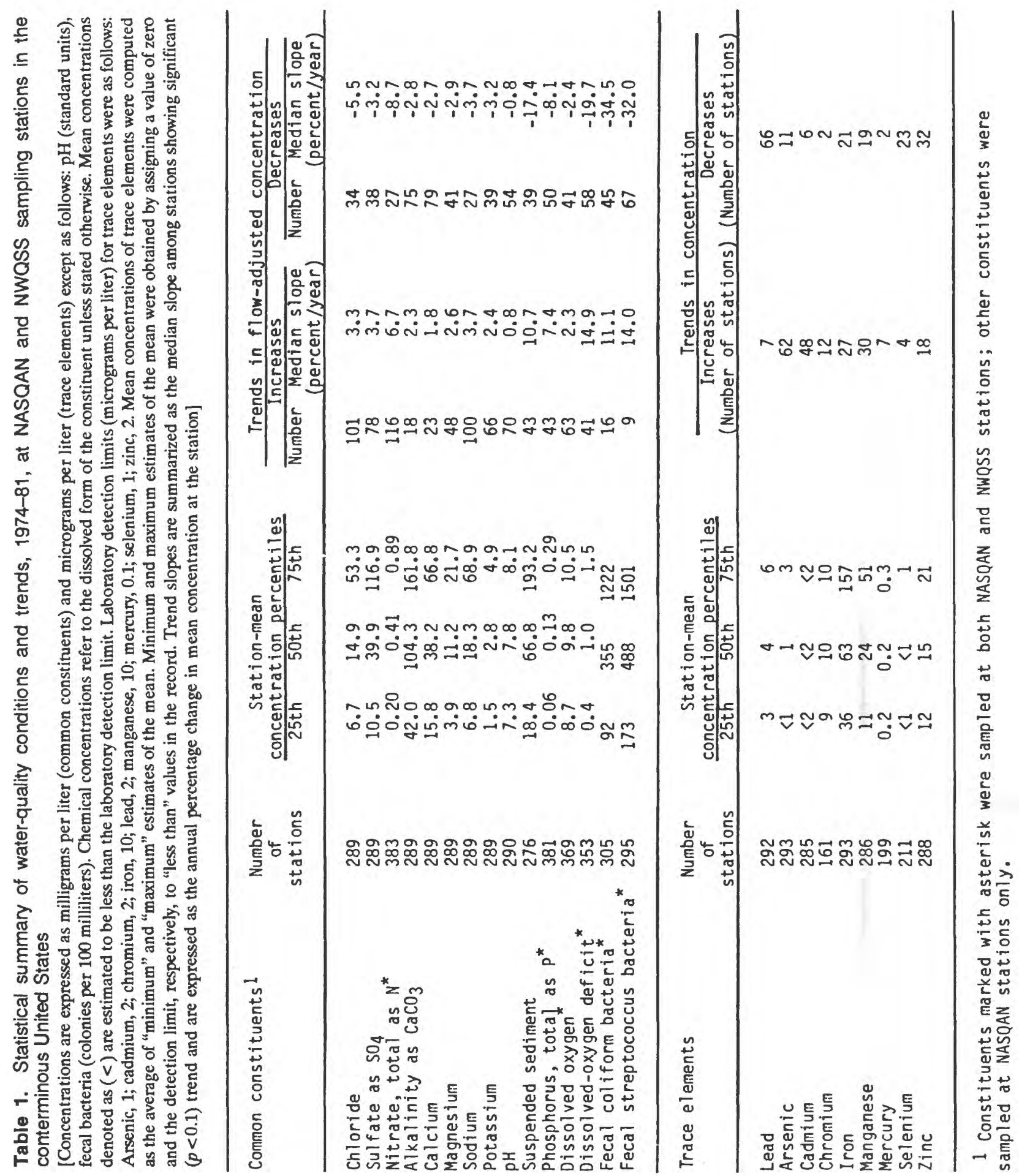


approached the problem of trend interpretation in three stages. First, through literature review we identified major regional sources of specific chemical and biological constituents, noting previous reports of regional trends. This information was used to develop an initial set of hypotheses.

Second, we investigated statistical associations among the observed water-quality trends and between the water-quality trends and various hydrologic characteristics of the basins upstream from the sampling stations (i.e., drainage area, flow frequency, flow regulation, and seasonal distribution of trends). Although these tests tended to show expected relationships between variables (e.g., wellknown correlations among common ions, and between suspended sediment and nutrients), in several instances the results suggested answers to basic questions about the causes of trends, such as the relative importance of point and nonpoint sources and of strong and weak acids.

Finally, we tested statistical associations between the observed trends and related data (table 2) describing population, land use, and known pollution sources in the basins upstream from the sampling stations. Contingency tables were constructed as either two-by-three or three-by-three arrays. Water-quality trends were grouped in three classes (increases, no trends, decreases) and were arrayed against either two or three classes of ancillary data, depending on the static or dynamic nature of the data. Unless otherwise specified, static measures of basin characteristics were divided at the median. When ancillary data described changing conditions over the period of study, three classes of roughly equal size were established indicating the direction of change (increase, decrease, little or no change). Significance of contingency tables was determined in chi square tests. In the results that follow, significance is reported as $p$, the probability that an apparent relationship between water-quality trends and ancillary data could have resulted solely from a chance arrangement of the data. For tables with expected frequencies less than 1 , or with more than 20 percent of expected frequencies less than 5 , significance was determined through enumeration of all possible table configurations (Agresti and others, 1979: Cantor, 1979). Point sources within the conterminous United States (see table 2) could be identified by river-reach number (DeWald and others, 1985) and located as a function of channel distance from the sampling stations. Industrial and agricultural land-use information (see table 2) was available either by cataloging unit or by county and was aggregated by basin through digitization of the drainage area above the stations (see example in fig. 2). Point-source contaminates include biochemical oxygen demand (BOD), kjeldahl nitrogen, total phosphorus, arsenic, cadmium, and lead (Gianessi and Peskin, 1984). Load estimates (Gianessi and Peskin, 1984) are based on flow records (for regularly discharging facilities) from the EPA Industrial Facility Discharge File (Taylor, 1983), and effluent-concentration estimates obtained in written communications from State pollution-control authorities and from values in published literature. Data on use of highway salt (Salt Institute, 1975, 1980) and consumption of leaded gasoline (Ethyl Corporation, 1982; Shelton and others, 1982) were compiled by State and apportioned to drainage basins on the basis of detailed population figures (U.S. Department of Commerce, 1970, 1983).

Several limitations of the interpretive methods should be emphasized. First, statistical associations between water-quality trends and basin conditions do not establish cause and effect. This limitation is especially significant when, by necessity, the ancillary data for interpreting trends take the form of static measures of basin characteristics rather than records of concurrent changes in conditions. Second, we assume that, in general, there are many causes of trends in each constituent, yet our approach, which depends on finding similarities in the nationwide distributions of variables, focuses only on factors of sufficiently widespread importance to significantly influence the overall pattern of trends. In sum, given the nature and scope of the analysis, we view this approach as preliminary hypothesis testing, serving to direct more intensive types of waterquality sampling and investigation in the future.

\section{TREND ANALYSIS AND INTERPRETATION}

\section{Chloride}

Increases in chloride concentrations (fig. 3) were extremely frequent and widespread at NASQAN stations over the 1974-81 study period. Chloride increases occurred in nearly all regional drainage systems, but were especially frequent in the Missouri, Mississippi, Ohio, and Atlantic Coastal basins (see fig. 1). Decreases in chloride were frequent only in the Great Lakes and Lower Colorado basins (fig. 1).

Chi square tests indicate that chloride trends are positively, though only moderately $(p=0.064)$, associated with basin population changes, 1970-80 (U.S. Department of Commerce, 1970, 1983). Human wastes are a major source of chloride in 


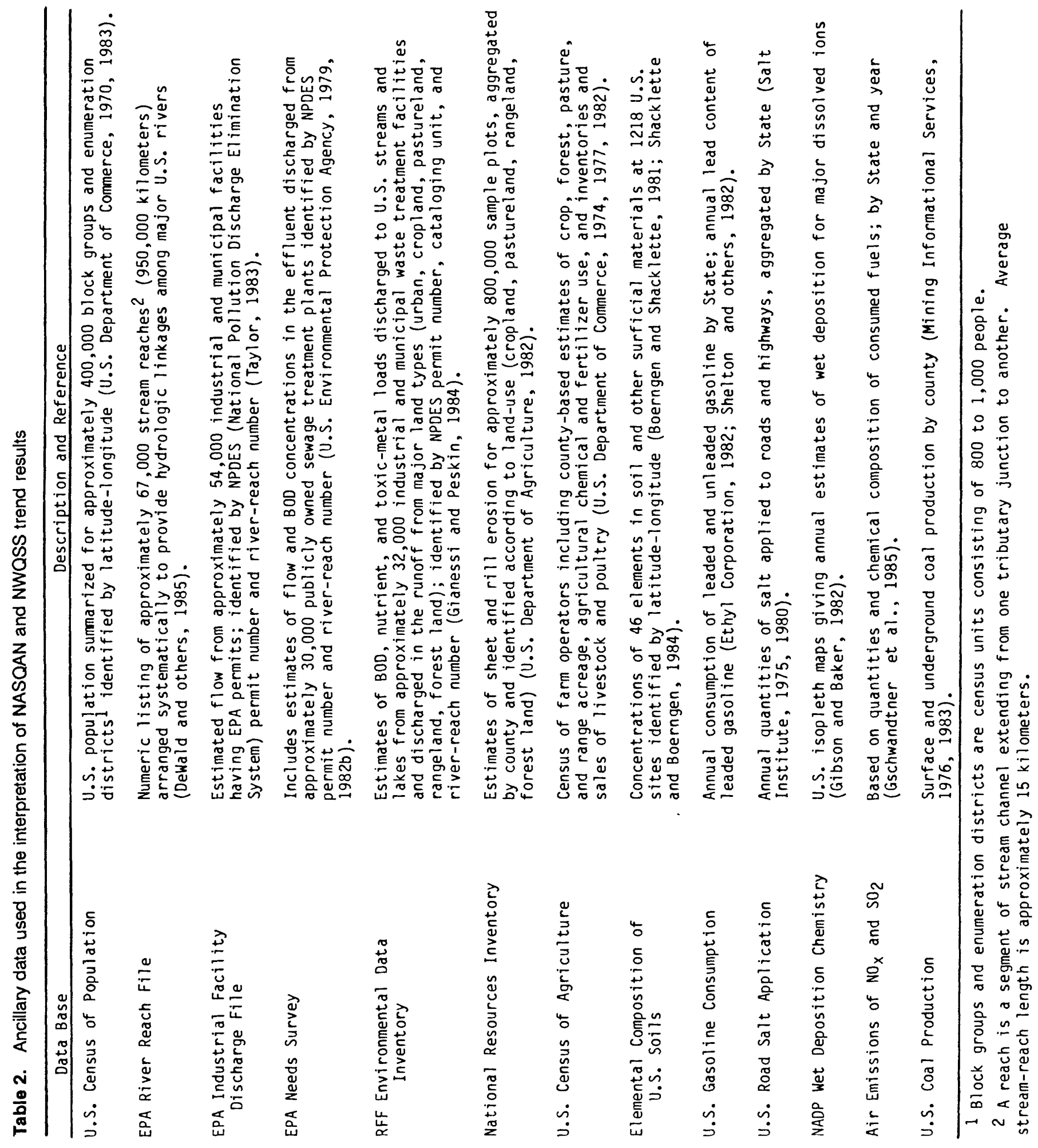




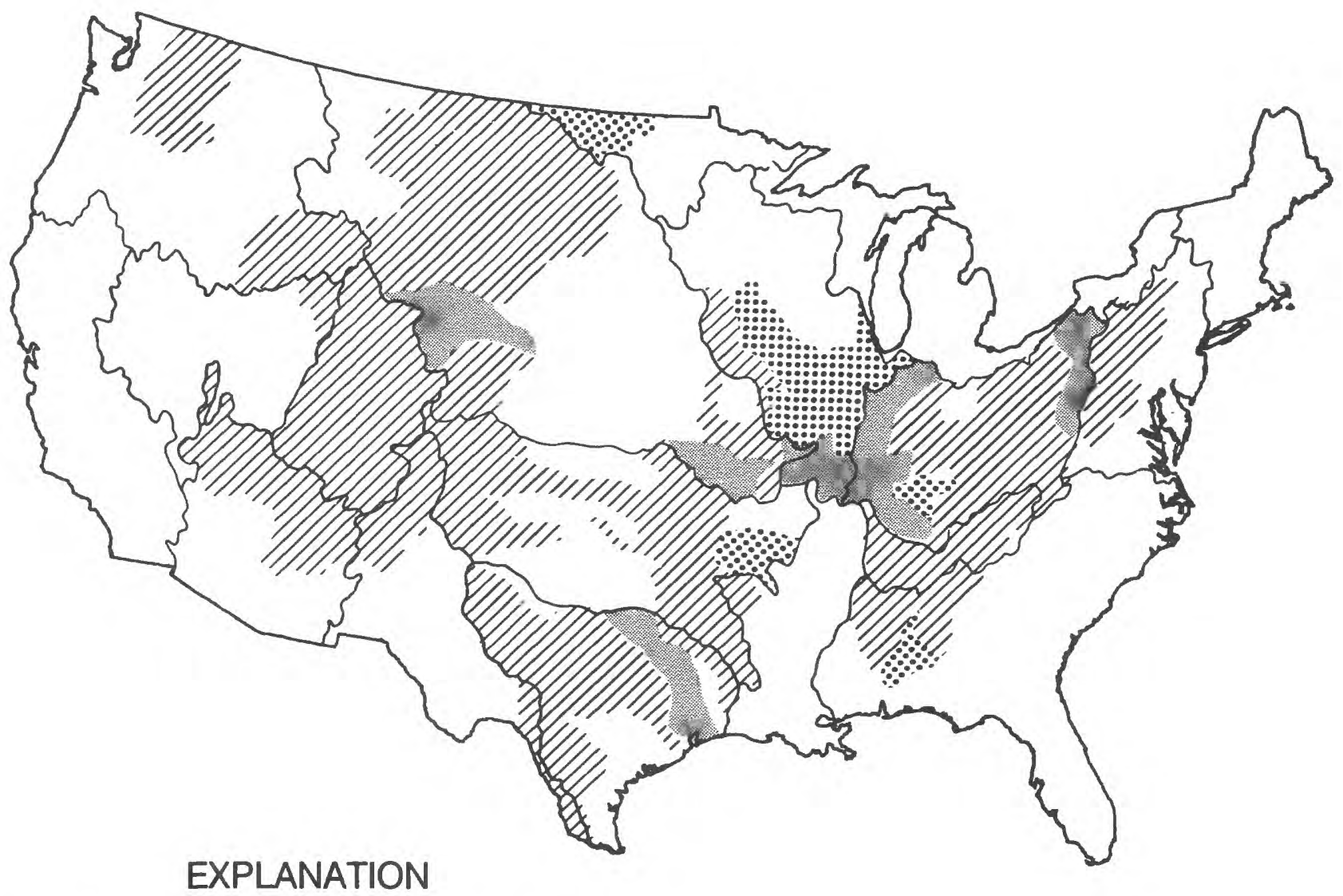

Boundary of Regional Drainage Basin

Change in Surface-Coal Production
$\square$ Greater Than 20 Percent Increase
Less Than 20 Percent Change
Greater Than 20 Percent Decrease
No Surface-Coal Production

Figure 2. Change in surface-coal production in NASQAN drainage basins, 1974-81. In this example of ancillary data used in the interpretation of causes of trends, county-level data were apportioned to NASQAN basins on an areal basis. NASQAN basins were then grouped into three classes on the basis of the direction of change in surface-coal production during the study period.

populated basins (Biesecker and Leifeste, 1975), but in chi square tests, chloride trends are not significantly related to changes in municipal effluent flows (U.S. Environmental Protection Agency, 1979, $1982 \mathrm{~b}$ ) in the basin. Highway-salt use increased nationally by a factor of more than 12 between 1950 and 1980 (Salt Institute, 1975, 1980) and stands out as a possible cause of chloride trends in basins where rates of salt use have reached appreciable fractions of the stream-transport rate of chloride (Scott, 1980; Peters and Turk, 1981). Chi square tests indicate that increasing chloride concentrations are significantly associated with high rates of highway-salt use (Salt Institute, 1975, 1980) in the basins $(p=0.013)$ and with high ratios of salt use to stream transport of chloride $(p=0.075)$. Moreover, chloride increases are strongly associated $(p=0.002)$ with increases in highway-salt use in the basins, 1975-80 (especially in the Ohio, Tennessee, lower Missouri, and Arkansas-Red basins). Irrigated agriculture is known to have a large influence on the salinity of certain western rivers (Jonez, 1984), but chloride trends are not significantly associated with either irrigated acreage or changes in irrigated acreage, 1974-82 (U.S. Department of Commerce, 1974, $1977,1982)$ in the basins. Decreases in chloride concentrations in the Colorado drainage are noteworthy in view of the history of salt problems in the basin and have been recently traced, in part, to the effects of reservoir filling during the early 1970's 


\section{Chloride}

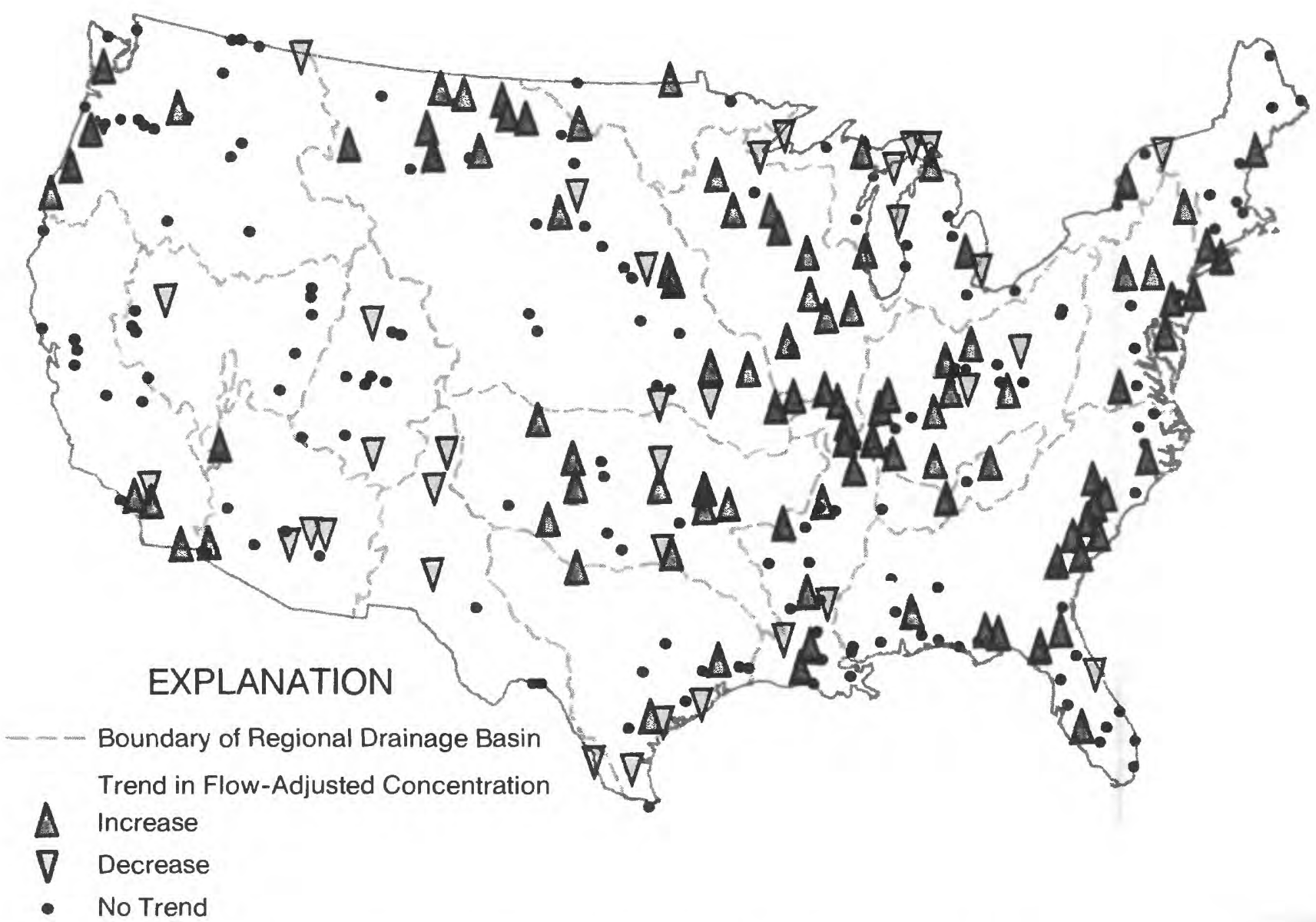

Figure 3. Trends in flow-adjusted concentrations of chloride at NASQAN stations, 1974-81.

(U.S. Department of the Interior, 1983). Nationally, however, both increasing and decreasing chloride trends occurred independently of the presence of reservoirs in the basins.

\section{Sulfate}

Increases in sulfate (fig. 4) outnumbered decreases by a ratio of nearly two to one. Increases were especially frequent in the Southeast and in the Missouri and Pacific Northwest basins. Decreases occurred mostly in the Northeast, especially in the Upper Mississippi, Great Lakes, and Ohio basins.

Important sources of sulfate in rivers include atmospheric deposition (wet and dry) and weathering of sulfur-bearing minerals. Sulfate trends in headwater streams have been previously related to trends in atmospheric sulfur emissions (Smith and
Alexander, 1983a, 1986). Moreover, the geographic pattern of trends in sulfur emissions over the 1974-81 period (Gschwandtner and others, 1985) is generally similar to that noted for stream-sulfate trends at NASQAN stations (i.e., decreasing in the Northeast, increasing in the Southeast and West). However, terrestrial sources of sulfur greatly exceed atmospheric deposition in many NASQAN basins, and the effects of mining (especially coal mining) and other forms of land disturbance on stream sulfate in pyrite-rich basins are well known (Helsel, 1983). The greater importance of terrestrial (over atmospheric) sources in relation to the observed trends is indicated by two relationships. First, there is a higher than expected frequency of trends in basins where the ratio of atmospheric deposition (Gibson and Baker, 1982) to aquatic yield of sulfur is low $(<0.2 ; p=0.039)$. Second, sulfate trends are highly associated with surface coal production 


\section{Sulfate}

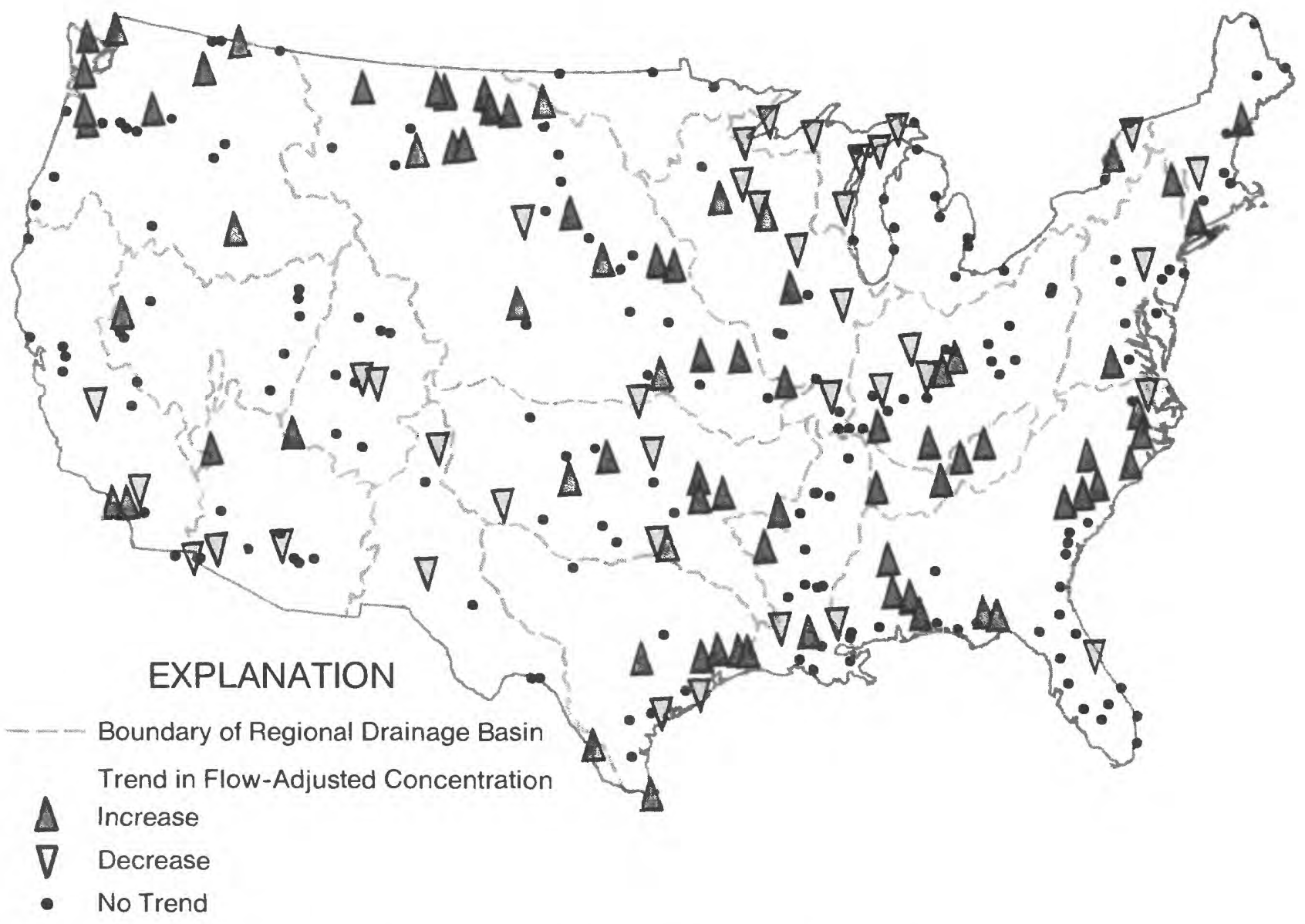

Figure 4. Trends in flow-adjusted concentrations of sulfate at NASQAN stations, 1974-81.

$(p=0.002)$ and change in surface coal production, $1974-81(p=0.002)$, in the basins (see fig. 2; Mining Informational Services, 1976, 1983). Sulfate trends are not significantly associated with underground coal production (Mining Informational Services, 1976, 1983), however.

\section{Nitrate}

Increases in nitrate concentrations (fig. 5) were extremely frequent and widespread among the 383 combined network stations, outnumbering decreases 116 to 27 . Increases were especially frequent east of the Mississippi River and in the Far Northwest. Decreases were scattered throughout the West, occurring most frequently in the Upper Colorado basin.

Major sources of nitrate in rivers include atmospheric deposition, agricultural runoff, and munici- pal and industrial wastes. Atmospheric deposition of nitrate (Gibson and Baker, 1982) exceeds basin yield at a majority of NASQAN stations (Smith and Alexander, 1984). Few nitrate-deposition records exist for 1974-81, but those that do (National Research Council, 1983) together with nitrous oxide $\left(\mathrm{NO}_{\mathrm{x}}\right.$ ) emission estimates (Gschwandtner and others, 1985), show a general pattern of increases. Increase in $\mathrm{NO}_{\mathrm{x}}$ emissions occurred in the MidAtlantic, Southeast-Gulf, Ohio, and Upper Mississippi basins and throughout much of the West. Consistent with this trend, nitrate increases at combined network stations occurred much more frequently than expected $(p=0.001)$ in basins receiving high levels (more than 10 kilograms per hectare per year) of atmospheric-nitrate deposition (especially the Ohio, Mid-Atlantic, Great Lakes, and Upper Mississippi basins). Agricultural inputs of nitrogen to surface water also increased during the 


\section{Nitrate}

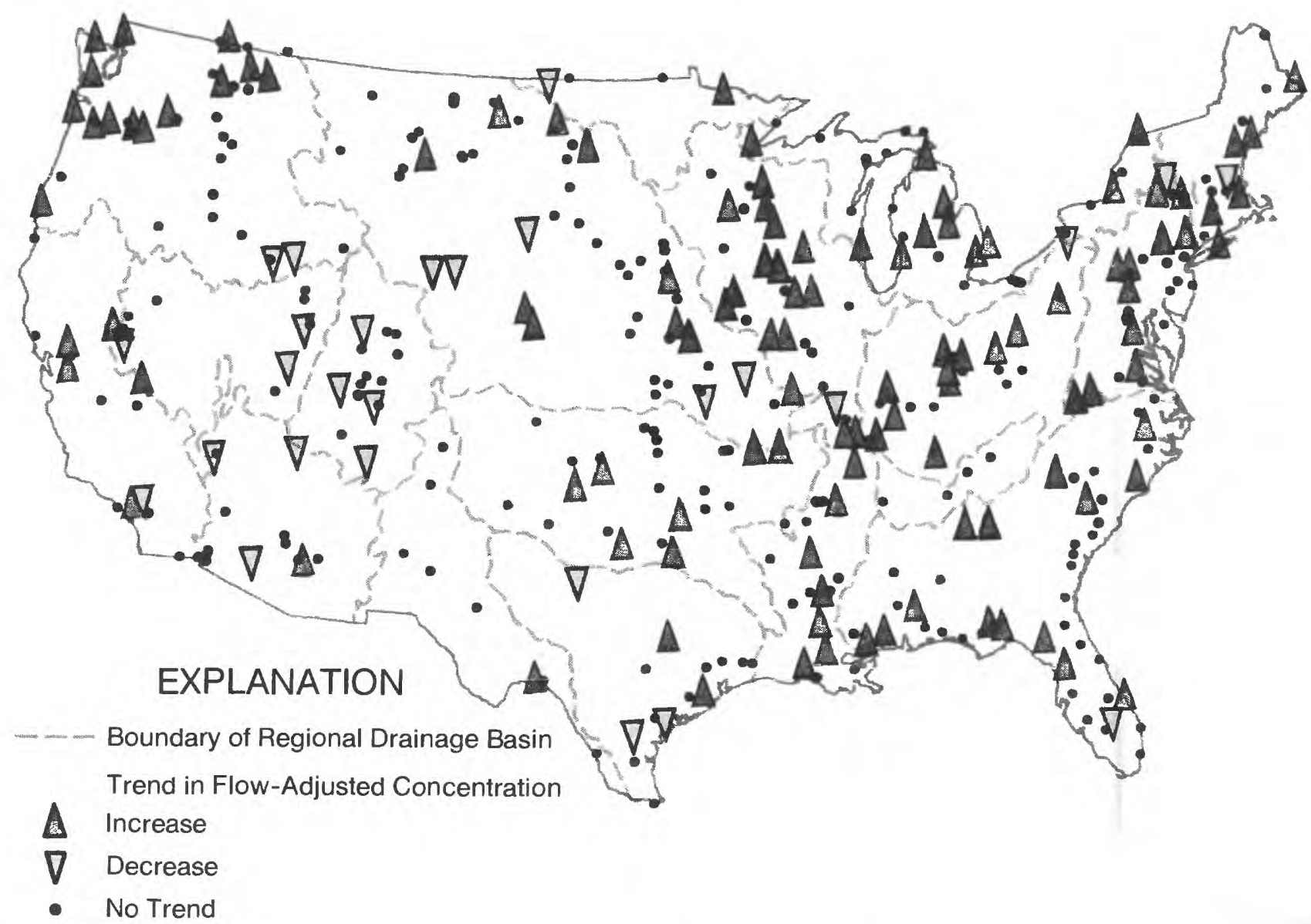

Figure 5. Trends in flow-adjusted concentrations of nitrate at NASQAN and NWQSS stations, 1974-81.

study period owing to a 38-percent increase in nitrogen-fertilizer use nationally (U.S. Department of Agriculture, 1983). Nitrate increases at combined network stations are strongly associated with high values of several measures of agricultural activity in the basins (U.S. Department of Commerce, 1974, 1977,1982 ), including fertilized acreage as a percentage of basin area $(p=0.006)$, livestock density $(p=0.016)$, and livestock sales $(p=0.040)$. Nitrate trends are also strongly associated with high rates of cropland erosion (U.S. Department of Agriculture, $1982)$ in the basin $(p<0.001)$. Point sources of nitrogen presumably declined during the latter 1970's as a result of major improvements in waste treatment (U.S. Environmental Protection Agency, 1980), but the magnitude of change is unknown. Nitrate trends at combined network stations are only weakly associated $(p=0.074)$ with changes in the fraction of municipal effluent receiving secondary or higher levels of treatment (U.S. Environmental Protection Agency, 1979, 1982b) within 50 kilometers upstream from the stations. Similar tests for distances up to 160 kilometers, as well as tests involving changes in the fraction of municipal effluent receiving either advanced secondary or tertiary treatment, were not significant. In sum, nitrate trends appear more related to nonpoint sources than to point sources, and, in particular, atmospheric deposition may have played a large role in the frequent occurrence of nitrate increases in rivers in the midwestern and mid-Atlantic portions of the United States.

\section{Alkalinity and Base Cations}

Decreases in alkalinity (fig. 6) were predominant over increases during the study period, occur- 


\section{Alkalinity}

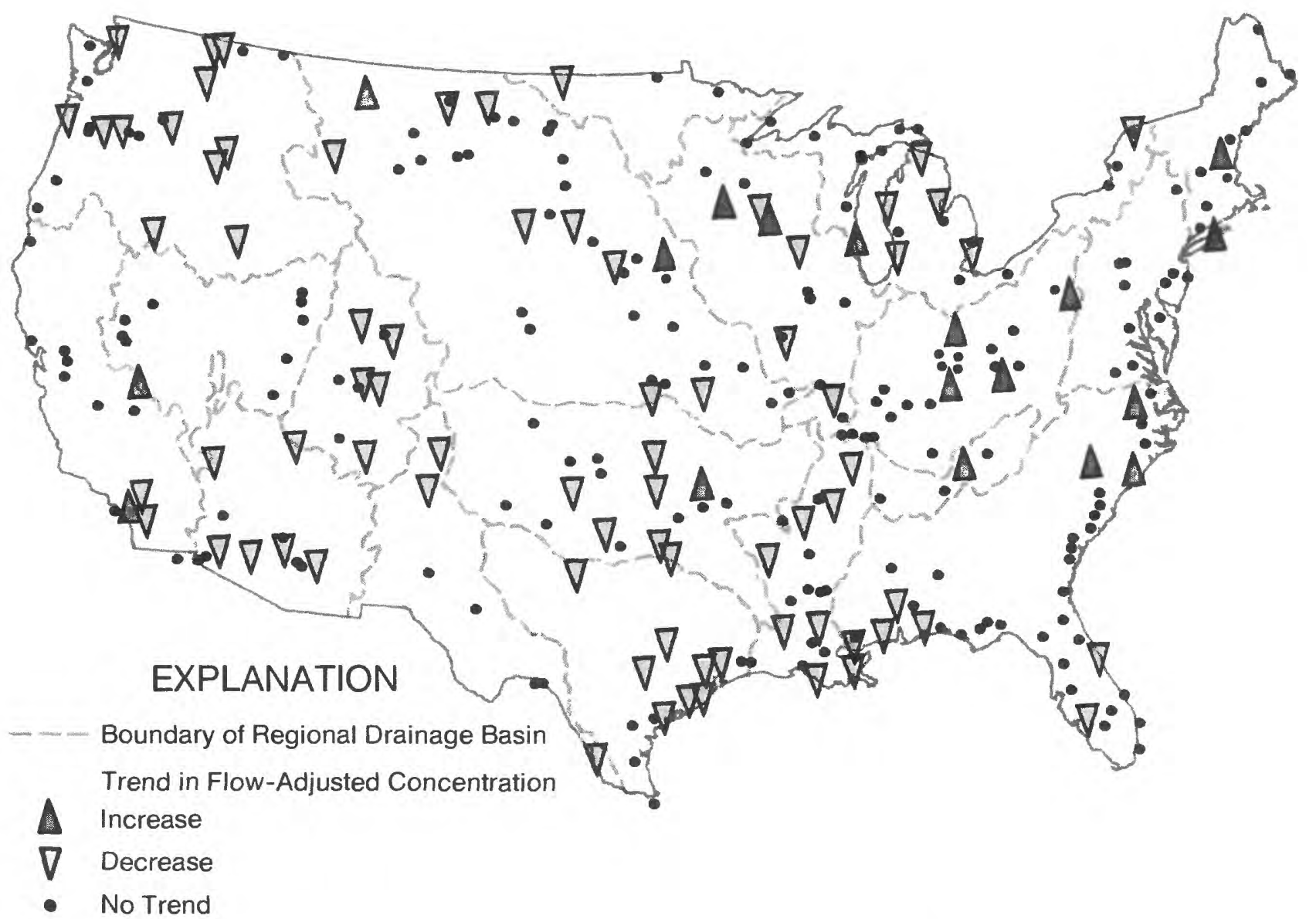

Figure 6. Trends in flow-adjusted concentrations of alkalinity at NASQAN stations, 1974-81.

ring frequently in the Lower Mississippi, TexasGulf, Lower and Upper Colorado, Missouri, and Pacific Northwest basins. Increases were not concentrated geographically, but occurred more commonly in eastern basins.

Reductions in stream alkalinity can result from the introduction of strong acids (mainly sulfuric acid and nitric acid) to the stream or from a variety of biological processes involving basin soils and vegetation. Important processes that introduce strong acids include atmospheric deposition (National Research Council, 1983) and the oxidation of sulfide minerals (Helsel, 1983). Other processes resulting in decreased stream alkalinity but not involving strong acids include reduction of soil carbon dioxide and the uptake of base cations during tree growth (Driscoll and Likens, 1982). An indication of the importance of strong acids in causing alkalinity trends can be obtained from tests of association between alkalinity trends and trends in sulfate and nitrate concentrations since these are the major strong-acid anions in surface waters. Sulfate and nitrate trends are significantly related to trends in alkalinity $(p=0.006$ and $p=0.0004$, respectively), but in a positive direction. That is, at stations showing decreases in alkalinity, increases in nitrate and sulfate occurred less frequently than expected, indicating that the observed alkalinity decreases did not generally result from the introduction of strong acids such as from acid deposition or acid mine drainage. Further evidence that widespread alkalinity decreases did not stem from inputs of strong acid, but were associated instead with other processes occurring in basin soils and vegetation, comes from the association between alkalinity trends and cation trends. Cation increases are expected to accompany alkalinity declines when the declines result from the neutralization of strong 


\section{Suspended Sediment}

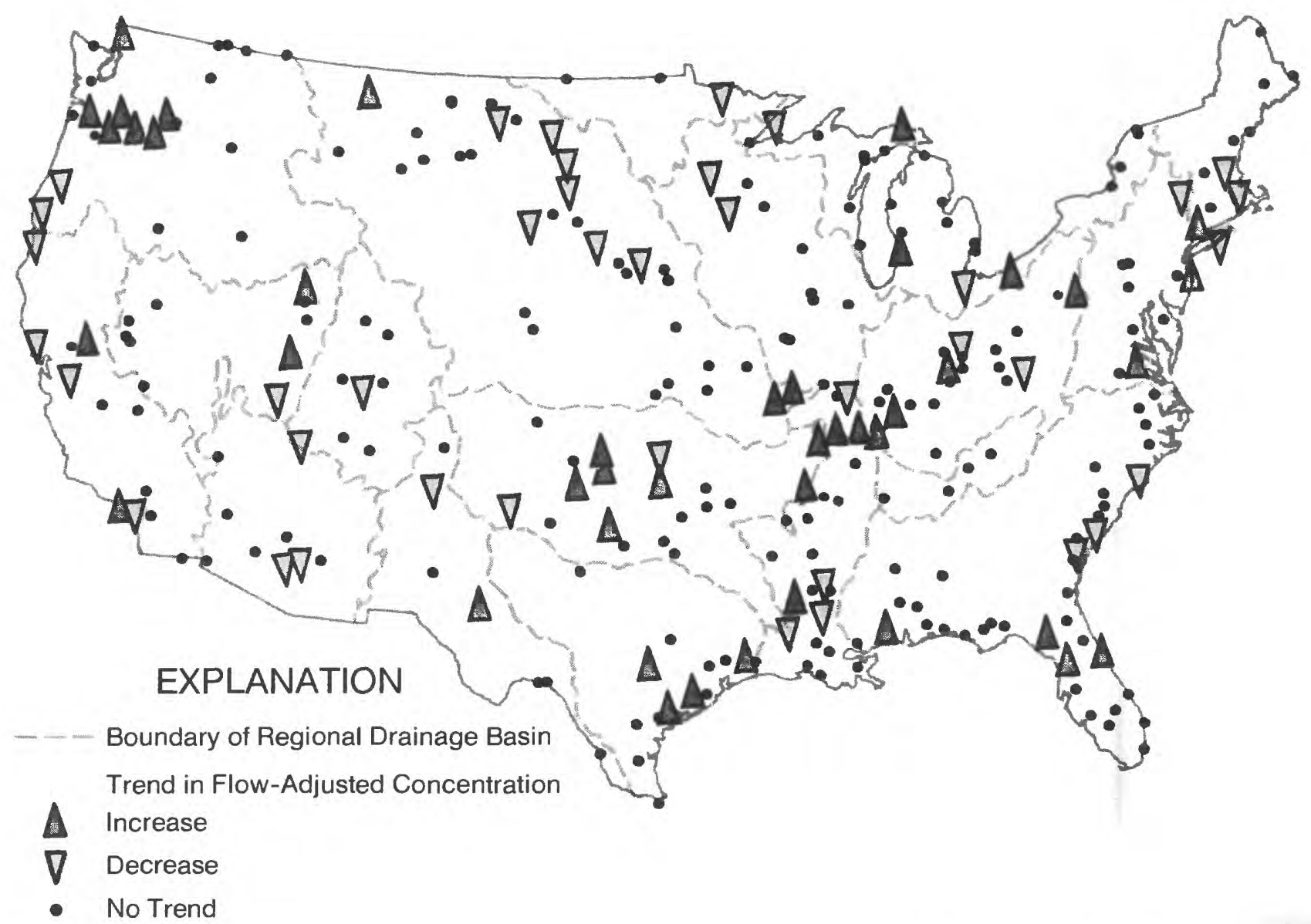

Figure 7. Trends in flow-adjusted concentrations of suspended sediment at NASQAN stations 1974-81.

acids, whereas cation decreases are generally associated with falling alkalinity when the alkalinity declines result from reductions in carbonic acid weathering or from the exchange of cations for hydrogen ions in growing forests (Driscoll and Likens, 1982; Kramer and others, 1986). Alkalinity decreases at NASQAN stations were strongly associated $(p<0.001)$ with decreases in major cations, especially calcium; more than half of the alkalinity decreases are coincident with calcium decreases.

Except for calcium, trends in major cations (sodium, potassium, and magnesium) were more frequently up than down. Trends in both directions were widely distributed, but cation increases were especially common in the Missouri basin and decreases were frequent in the Lower Colorado basin. Sodium trends were mostly up (100 of a total of 127) and followed a distribution that is almost identical to that of chloride trends, suggesting a common origin for trends in both.

\section{pH}

Increases in $\mathrm{pH}$ occurred most frequently in the Ohio basin and along the Texas-Gulf Coast; decreases in $\mathrm{pH}$ were frequent in the Lower Mississippi basin and along the Atlantic Coast.

Several lines of evidence suggest that the major causes of $\mathrm{pH}$ trends at NASQAN stations involve biological processes, such as instream photosynthesis and respiration (Stumm and Morgan, 1981), which potentially have a large effect on $\mathrm{pH}$ but do not have a large influence on alkalinity. First, $\mathrm{pH}$ trends are not even weakly associated with trends in alkalinity or strong-acid anions (i.e., sulfate and nitrate). Moreover, $\mathrm{pH}$ trends are, in almost 
all cases, far too large to be explained by observed changes in either alkalinity or acid anions given the prevailing alkalinities at stations showing $\mathrm{pH}$ trends.

\section{Suspended Sediment}

Nationwide, nearly equal numbers of stations showed increases and decreases in suspended-sediment concentrations, but within certain regions trends were predominantly in the same direction (fig. 7). Decreases occurred on several tributaries to the Missouri River while increases were frequent in the basins of the Arkansas, Red, Columbia, Lower Mississippi, and Ohio Rivers.

The regional pattern of suspended-sediment trends suggests a variety of causative factors. Many streams in the Columbia River basin carried increased sediment loads following eruptions of Mount St. Helens during 1980-81 (Haeni, 1983). Declining concentrations for several locations in the Missouri River basin have been previously reported and have been clearly traced to the effects of reservoir construction throughout the basin during the 1950's and 1960's (Williams and Wolman, 1984). The effects of reservoirs on suspended-sediment concentrations may be observed for very long periods of time after construction as a new equilibrium between sediment transport and deposition in the channel is established. A test of association between sediment trends and the fraction of the drainage basin located upstream from reservoirs was not significant, however. Thus, although reservoirs are known to be responsible for suspended-sediment decreases in the Missouri basin, they do not appear to be a major factor in the nationwide occurrence of trends.

Increasing sediment concentrations occurred in several basins in which the predominant forms of land use are associated with high rates of soil erosion (e.g., logging in the Columbia River basin, agriculture in the Arkansas-Red and Mississippi basins). Sediment trends are not significantly associated with estimates of total basin soil erosion, but sediment increases are positively related $(p=0.020)$ to the fraction of total soil erosion contributed by cropland in the basin (U.S. Department of Agriculture, 1982). Also, sediment increases occurred more frequently than expected ( $p=0.078$ ) where the cropland erosion rate is high in absolute terms (more than 5,600 kilograms per hectare per year). In contrast, sediment trends are not associated with erosion rates on either forest land, pastureland, or rangeland. The apparent relationship between sed- iment trends and cropland erosion is interesting but is difficult to interpret because of the static nature of the soil-erosion estimates. Sediment trends were also compared with the change in estimated soil erosion, 1977-82 (U.S. Department of Agriculture, 1982), for various rural land-use classifications in the basins and were not significantly related. The apparent inconsistency may stem from a lack of comparability of the erosion estimates for different years (U.S. Department of Agriculture, 1982). Moreover, lags frequently occur in the response of stream-sediment concentrations to changes in erosion rates owing to the effects of basin storage of sediment (Trimble, 1981; Meade and Parker, 1985).

\section{Total Phosphorus}

Nearly equal numbers of stations showed increases and decreases in total phosphorus concentrations, but as with suspended sediment, trends were predominantly inthe same direction in certain regions. Decreases occurred frequently in the Great Lakes and Upper Mississippi basins, while increases occurred throughout the Southeastern United States.

Despite the predominance of nonpoint sources of phosphorus nationally, point sources contribute significantly to total phosphorus concentrations in certain regions, especially the New England, MidAtlantic, and Great Lakes basins (Gianessi and Peskin, 1981). Phosphorus decreases at combined network stations in the Great Lakes region probably result, in part, from point-source reductions achieved in the region in the late 1970's (Rockwell and others, 1980; Hartig and Horvath, 1982). Several lines of evidence suggest that observed phosphorus decreases stem generally from point-source reductions, while observed increases in phosphorus result from nonpoint-source increases. Tests of association between phosphorus trends and various static measures of phosphorus point sources (pointsource load, point-source load/streamflow, pointsource/nonpoint-source load) (Gianessi and Peskin, 1984) within 160 kilometers upstream from combined network stations are significant $(p=0.003$, 0.002 , and 0.045 , respectively) mainly because of the frequent coincidence of phosphorus decreases with large point-source loads. Evidence for the importance of nonpoint sources in relation to trends, however, lies in a strong statistical association $(p<0.001)$ between phosphorus trends and trends in suspended sediment. Moreover, phosphorus increases are associated with high values of various static measures (U.S. Department of Commerce, 
Table 3. Tests of association between trends in dissolved-oxygen deficit (DOD) and various measures of municipal biochemical oxygen demand (BOD) loads upstream from combined network stations

[Tests 1 and 2 employed static measures of BOD (i.e., average values during the study period), while tests 3 through 6 considered changes in BOD resulting from treatment plant expansion and upgrading during 1977-81. Tests 7 through 10 considered various transformations of the DOD and BOD data designed to enhance the degree of association. The results of the tests (expressed as $p$, the significance level) indicate only weak association between trends in DOD and BOD load changes. The value of $p$ is the probability of incorrectly rejecting the null hypothesis that trends in DOD occur independently of changes in BOD or level of BOD]

\begin{tabular}{|c|c|c|c|}
\hline \multicolumn{3}{|c|}{ Test criteria } & \multirow{2}{*}{$\begin{array}{l}\text { Results } \\
\text { (p) }\end{array}$} \\
\hline $\begin{array}{l}\text { BOD } \\
\text { lno. }\end{array}$ & $\begin{array}{l}\text { or DOD criteria } \\
\text {.) }\end{array}$ & $\begin{array}{l}\text { Distance upstream } \\
\text { from stations } \\
\text { (kilometers) }\end{array}$ & \\
\hline $\begin{array}{l}1 \\
2\end{array}$ & $\begin{array}{l}\text { Point-source load/ nonpoint- } \\
\text { source load ratio } \\
\text { Industrial/municipal }\end{array}$ & $\begin{array}{l}160 \\
160\end{array}$ & $\begin{array}{c}10.047 \\
0.15\end{array}$ \\
\hline $\begin{array}{l}3 \\
4 \\
5 \\
6\end{array}$ & $\begin{array}{l}\text { Municipal load changes }(1978-81) \\
\text { Do. } \\
\text { Do. } \\
\text { Do. }\end{array}$ & $\begin{array}{r}160 \\
80 \\
50 \\
25\end{array}$ & $\begin{array}{l}0.42 \\
0.37 \\
0.24 \\
0.59\end{array}$ \\
\hline $\begin{array}{r}7 \\
8 \\
9 \\
10\end{array}$ & $\begin{array}{l}\text { Low flows only } \\
\text { Adjust for decay, reaeration } 2 \\
\text { High deficit stations only } \\
\text { High point-source load/nonpoint- } \\
\text { source load ratio }\end{array}$ & $\begin{array}{r}160 \\
160 \\
50 \\
50\end{array}$ & $\begin{array}{r}0.62 \\
0.88 \\
10.08 \\
0.12\end{array}$ \\
\hline
\end{tabular}

\footnotetext{
lsignificant at the $p<0.1$ level.

2 streeter-phelps equation.
}

$1974,1977,1982)$ of agricultural land use (fertilized acreage, $p=0.103$; cattle-population density, $p=0.002$ ).

\section{Dissolved-Oxygen Deficit}

Dissolved-oxygen deficit (DOD) is calculated as the saturation concentration at the prevailing temperature minus the actual dissolved-oxygen concentration. Trends in dissolved oxygen are potentially caused either by changes in chemical (COD) or biochemical oxygen demand (BOD) or by temperature change through its effect on the solubility of oxygen. Thus, temperature effects can be largely corrected for by converting the oxygen-concentration data to time series of dissolved-oxygen deficit prior to trend testing. Decreases in DOD (i.e., increases in dissolved-oxygen concentrations) outnumbered increases 58 to 41 out of a total 353 stations. There is no pronounced geographic pattern to the DOD trends, although decreases were most frequent in the New England, Mid-Atlantic, Ohio, and Upper and Lower Mississippi basins while increases were frequent in basins in the Southeast and the Far Northwest.

An important hypothesis to consider is that the greater frequency of DOD decreases over increases reflects the success of major efforts to reduce BOD in municipal and industrial effluents (U.S. Environmental Protection Agency, 1982a, 1984). In the decade following passage of the Clean Water Act in 1972, total municipal BOD loads decreased an estimated 46 percent (ASIWPCA, 1984) and industrial BOD loads decreased at least 71 percent (U.S. Environmental Protection Agency, 1982a), despite increases in population and real gross national product of 11 percent and 25 percent, respectively. Industrial sources currently contribute about one-third of the total point-source BOD load nationwide (Gianessi and Peskin, 1984), and there is reason to believe that the decline in industrial loads took place slightly earlier (mid to late 1970's) than the decline in municipal loads (U.S. Environmental Protection Agency, 1977). Funding for the upgrading of municipal facilities under the EPA's Construction Grants Program reached its highest levels in 1979 and 1980 (Congressional Budget Office, 1984). The Construc- 
tion Grants Program has been the primary source of funds for the construction of publicly owned wastetreatment facilities in the United States (Congressional Budget Office, 1984).

Many case studies (U.S. Environmental Protection Agency, 1980; Leo and others, 1984) have attributed increases in stream dissolved-oxygen concentrations to improvements in waste-treatment facilities. The most comprehensive and best documented of these is the study by Leo and others (1984) in which data sets for 52 municipal facilities were screened to yield 13 case examples with sufficient data to properly test a hypothesis linking improved waste treatment to change in the water quality of rivers receiving waste materials. Of these 13 sites, 10 showed clear evidence of lowered DOD in the vicinity of maximum oxygen deficit immediately downstream from the treatment plant.

A major question left unanswered by case studies of increased waste treatment, however, concerns the nationwide extent of improved dissolvedoxygen conditions. Recent nationwide assessments (U.S. Environmental Protection Agency, 1982a; ASIWPCA, 1984) suggest that widespread, visible improvements in water quality have occurred and are attributable largely to point-source BOD reductions in the decade following enactment of the Clean Water Act. However, these assessments are based on surveys of State and local pollution-control personnel and are expressed in terms of broadly defined water-quality conditions rather than DOD per se. Modeling studies (Gianessi and Peskin, 1981) indicate that point-source $\mathrm{BOD}$ reductions slightly larger than those achieved by 1982 would result in detectable DOD changes in about 7 percent of river reaches nationwide.

Comparisons of observed trends in DOD with static measures of BOD loads (table 3) indicate a moderate association between DOD trends and the ratio of point-source to nonpoint-source BOD load (Gianessi and Peskin, 1984) upstream from the stations $(p=0.047)$. Decreases occur more frequently than expected where point sources are dominant, and increases, where nonpoint sources are dominant. Less statistically significant ( $p=0.15)$, but of some interest, nevertheless, is the tendency for DOD decreases to occur more frequently where the industrial contribution (Gianessi and Peskin, 1984) to total point-source BOD load is large. This finding is consistent with evidence (U.S. Environmental Protection Agency, 1977) that major increases in industrial treatment preceded the surge in construction and upgrading of municipal facilities under the Construction Grants Program. Data are available (U.S. Environmental Protection Agency, 1979, 1982b) to develop site-specific estimates of change in load only for municipal facilities for the period 1977-81. Changes in municipal loads during 1977-81, however, are believed (Congressional Budget Office, 1984) to constitute the large majority of changes occurring during the study period. No significant relationship was found between trend in DOD and change in BOD loads from municipal treatment plants within 160 kilometers upstream from the stations. Reducing the distance over which BOD loads were summed in computing load changes gave progressively higher numerical significance levels, but even at the apparent optimum of 50 kilometers, chi square results showed little sign of association $(p=0.24)$ between load changes and DOD trends. Additional steps to specifically consider trends under low-flow conditions (lower 25 percent of flow-frequency distribution) and dilution and reaeration effects on BOD loads gave even lower significance levels. A Streeter-Phelps model was constructed for river reaches within 160 kilometers of combined network stations in order to account for the effects of dilution and reaeration on dissolvedoxygen demand. Stream velocities were estimated as a function of streamflow (Leopold and Maddock, 1953). Expressions for deoxygenation (k1) and reaeration $(\mathrm{k} 2)$ were obtained from W.B. Langbein and W.H. Durum (1967) and were varied as a function of temperature $(\mathrm{k} 1)$ and temperature and streamflow (k2). Stratifying the stations to consider only those with mean DOD higher than 0.50 milligrams per liter or point-source/nonpoint-source load ratios (Gianessi and Peskin, 1984) higher than 0.2 gave the most significant results $(p=0.08$ and $p=0.12$, respectively).

Overall, these results provide, at best, weak evidence that the distribution of trends in DOD reflects the effects of point-source BOD reductions. The general inability to demonstrate a relationship between observed DOD trends and recorded changes in municipal BOD loads seems somewhat surprising in view of the magnitude of change in loads that has occurred and the number of case studies (U.S. Environmental Protection Agency, 1980; Leo and others, 1984) demonstrating local improvements from increased treatment. The poor correlation with municipal load changes might be explained, in part, by a greater effect of industrial load changes (see table 3), but a more likely explanation is that most combined network stations are simply too distant from municipal point sources to detect the effects of waste-load changes. Dissolved-oxygen variability at combined network stations is such that net DOD changes (1974-81) smaller than about 0.75 milligram per liter are generally not detectable in trend 


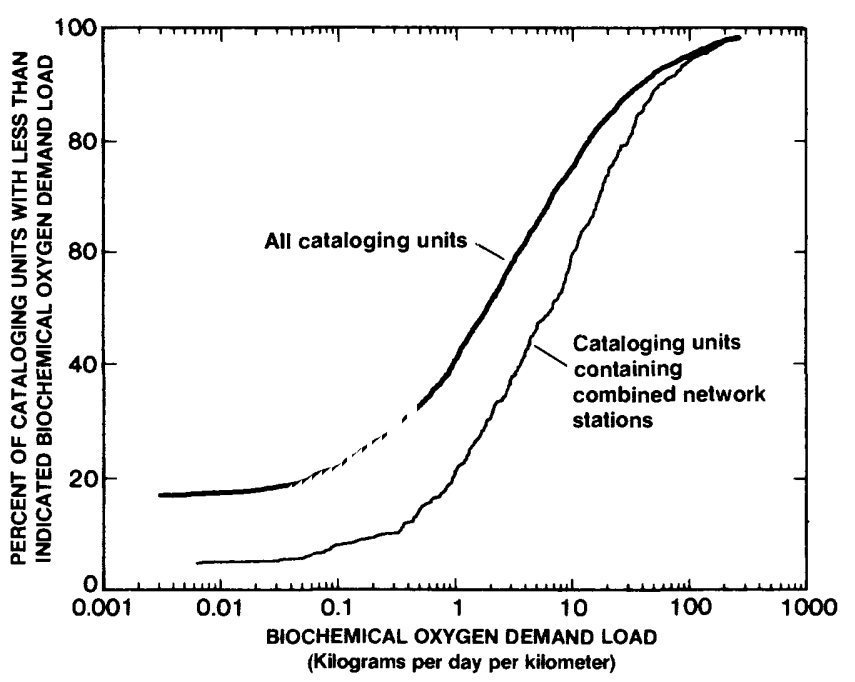

Figure 8. Comparison of the distribution of point-source biochemical oxygen demand loads for river reaches in cataloging units containing combined network stations with the similar distribution for all cataloging units. Cataloging units are typically 2,000-3,000 square kilometers in size and have a principal channel length of about 150 kilometers. Stream reaches in the vicinity of combined network stations carry somewhat higher biochemical oxygen demand loads than do stream reaches in general.

tests. This possibility is strengthened by the fact that chi square results improve systematically with decreasing distance between the stations and municipal sources, and with stratification of the network to focus on stations more heavily influenced by point sources.

As a sample of nationwide water-quality conditions, however, combined network stations are moderately biased toward higher point-source loads (fig. 8), suggesting that the effects of increased treatment should be somewhat more observable at these stations than in the Nation's rivers in general. Therefore, the inability to clearly demonstrate the effects of increased municipal treatment on DOD trends at combined network stations, while not inconsistent with case studies of specific point sources (U.S. Environmental Protection Agency, 1980; Leo and others, 1984), does appear to be at odds with other recent assessments (U.S. Environmental Protection Agency, 1982a; ASIWPCA, 1984) citing more far reaching effects. Statistically, load reductions appear to explain observed improvements in dissolved oxygen at fewer than 5 percent of stations showing an improving trend or 2 percent of all stations. In addition, load reductions may be associated with maintenance of dissolved-oxygen concentrations (i.e., no trend) at as many as 5 percent of all stations. These estimates are based on the 95-percent confidence limits of individual contingency table elements assumed to be Poissondistributed (Fienberg, 1980). Given the bias in the location of combined network stations toward higher point-source loads (fig. 8), the effect of BOD-load reductions on DOD levels among all stream reaches is probably somewhat smaller.

\section{Fecal Coliform and Fecal Streptococcus Bacteria}

The geographic distributions of trends in fecal coliform (FC) and fecal streptococcus (FS) bacteria are quite similar, although FS decreases were noticeably more frequent than FC decreases nationally (see table 1). Decreases in FS bacteria were especially common in areas along the Gulf Coast, in the central part of the Mississippi River basin, and in the Columbia River basin (fig. 9). Decreases in both forms of bacteria occurred frequently in the Arkansas-Red basin and along the Atlantic Coast. There are no clear regional patterns to the relatively few increases in either form of bacteria.

There is a significant statistical association in the occurrence and direction of trends in FC and FS bacteria, suggesting common causes for the trends in both in many cases. It is not evident, however, from the geographic distribution of trends whether point sources (human) or nonpoint sources (agricultural) are a more important explanation of trends. As with DOD, decreases in aquatic bacteria counts have been linked in case studies (e.g., Susquehanna and Chattahoochee Rivers) to improvements in sewage treatment during the study period (U.S. Environmental Protection Agency, 1980). A major emphasis of the Construction Grants Program has been the achievement of secondary treatment as a minimum standard, which has led to the establishment of centralized collectionand treatment of municipal wastes for the first time in many communities (U.S. Environmental Protection Agency, 1984). Also, increased regulation of animal wastes in agricultural runoff (Federal Register, 1976) occurred during the late 1970's, with the objective of reducing levels of bacteria in streams. Thus, an important question is whether point-source or nonpoint-source controls are more strongly associated with observed decreases in FC and FS bacteria.

One frequently used indicator of the source of bacterial contamination in natural waters is the FC/FS ratio (Thomann, 1972). Although this ratio is reliable only as a relative index, higher values of the ratio $(>4)$ are generally associated with human sources and lower values of the ratio $(<1)$ with 


\section{Fecal Streptococcus Bacteria}

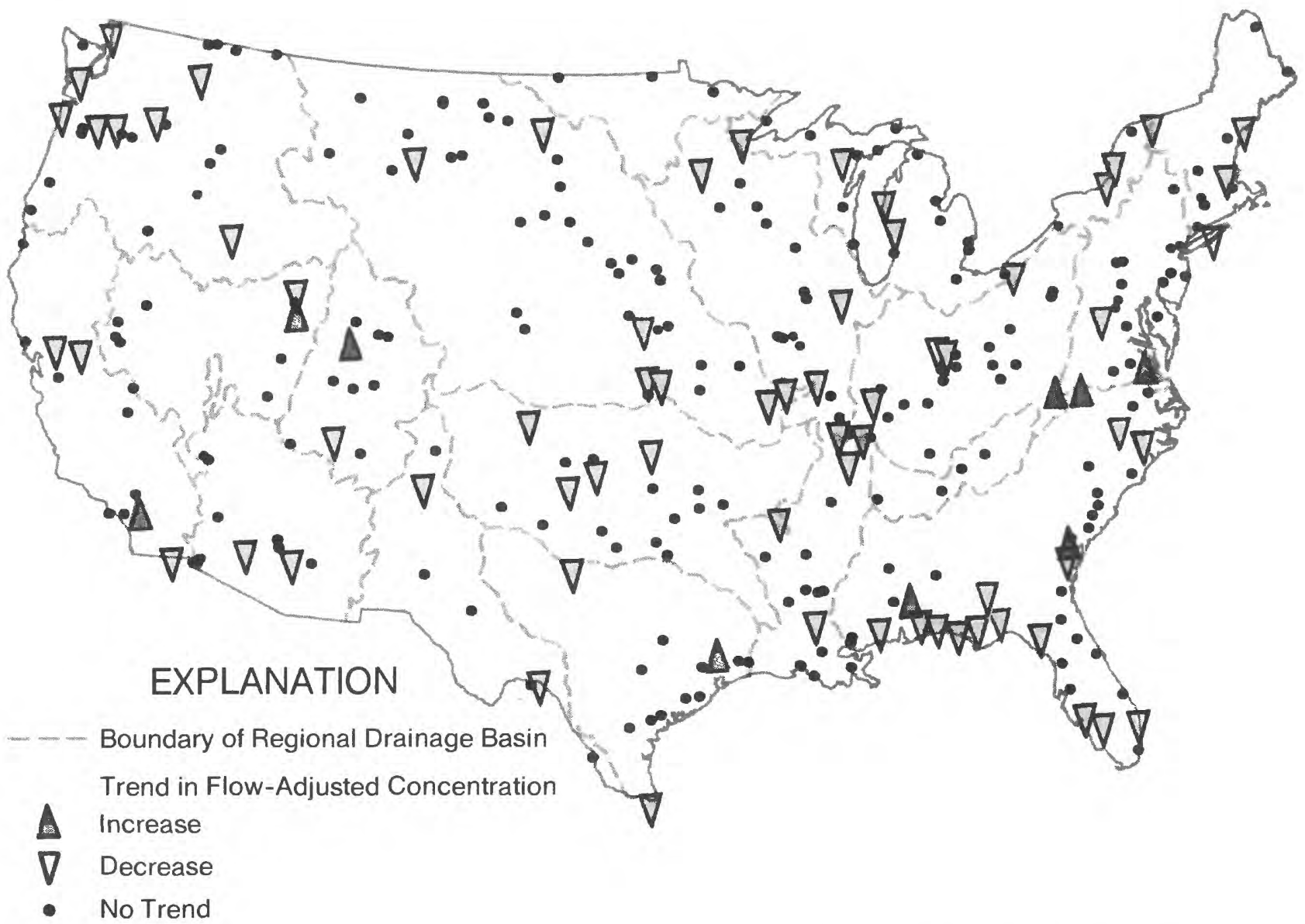

Figure 9. Trends in flow-adjusted concentrations of fecal streptococcus bacteria at NASQAN and NWQSS stations, $1974-81$.

animal sources. Chi square tests of association between trends in fecal bacteria and the FC/FS ratio indicate that decreases in both types of fecal bacteria occur more frequently in basins having greater human sources of bacteria (FC, $p=0.05$; FS, $p=0.03$ ). Tests of association between fecal bacteria trends and various measures of change in sewage treatment (U.S. Environmental Protection Agency, $1979,1982 \mathrm{~b}$ ) in combined network basins during the period of study also suggest that point sources are somewhat more important than nonpoint sources in explaining observed decreases. Decreases in both forms of bacteria are moderately associated with increases in the fraction of municipal effluent receiving secondary (or greater) treatment within 50 kilometers of combined network stations (FC, $p=0.056 ; \mathrm{FS}, p=0.070$ ). In contrast, $\mathrm{FC}$ increases are positively associated with cattle-population density $(p=0.010)$ as well as cattle sales $(p=0.009)$ in the basins (U.S. Department of Commerce, 1974, $1977,1982)$. In summary, there is evidence that (1) widespread decreases in fecal bacteria are primarily traceable to improved municipal waste treatment, and (2) the less frequent increases in FC counts are primarily associated with livestock wastes.

\section{Lead}

Decreases in dissolved-lead concentrations (fig. 10) greatly outnumbered increases, occurring frequently along the east and west coasts and in tributaries to the Missouri and Mississippi Rivers. The few increases in lead that did occur are clustered along the Texas-Gulf Coast and in the Lower Mississippi basin.

A likely explanation for the large number of decreases in stream-lead concentrations is a 67 - 


\section{Dissolved Lead}

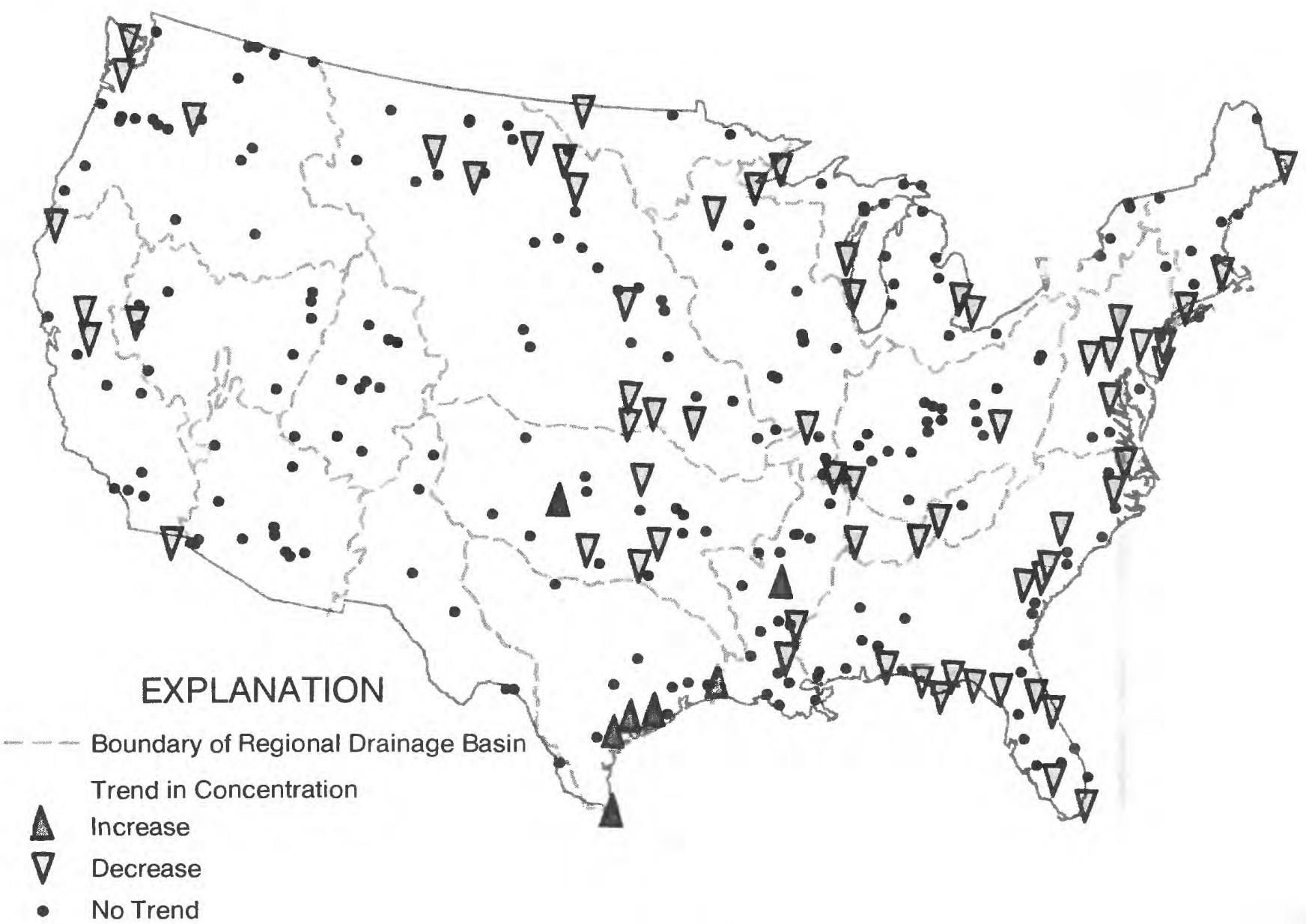

Figure 10. Trends in dissolved lead at NASQAN stations, 1974-81.

percent decline in gasoline-lead consumption (Ethyl Corporation, 1982; Shelton and others, 1982) that occurred from 1975 to 1981 (fig. 11). Gasoline lead is recognized as the major source of atmospheric lead (Edwards and Wheat, 1978; U.S. Environmental Protection Agency, 1983), although its distribution in aquatic systems is less well known. Similar declines in airborne lead have been reported for many U.S. cities (U.S. Environmental Protection Agency, 1983), and declines in lead concentrations in bulk precipitation (Likens, 1983), stream water (Turner and others, 1985), and lake sediments (Conservation Foundation, 1984) have been observed at a limited number of sites in the Northeast.

Decreases in stream-lead concentrations at NASQAN stations are highly associated with both

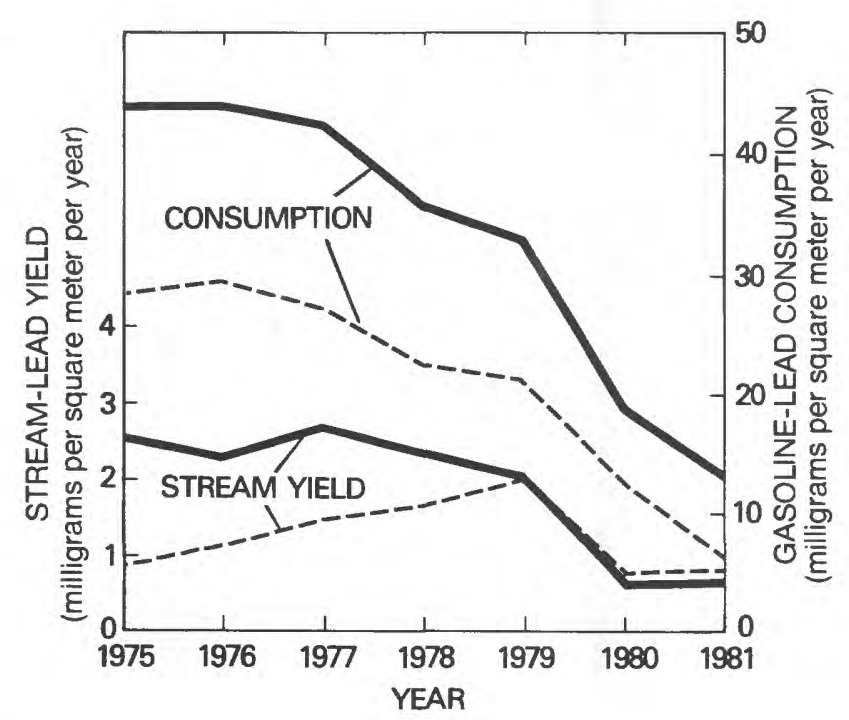




\section{Dissolved Arsenic}

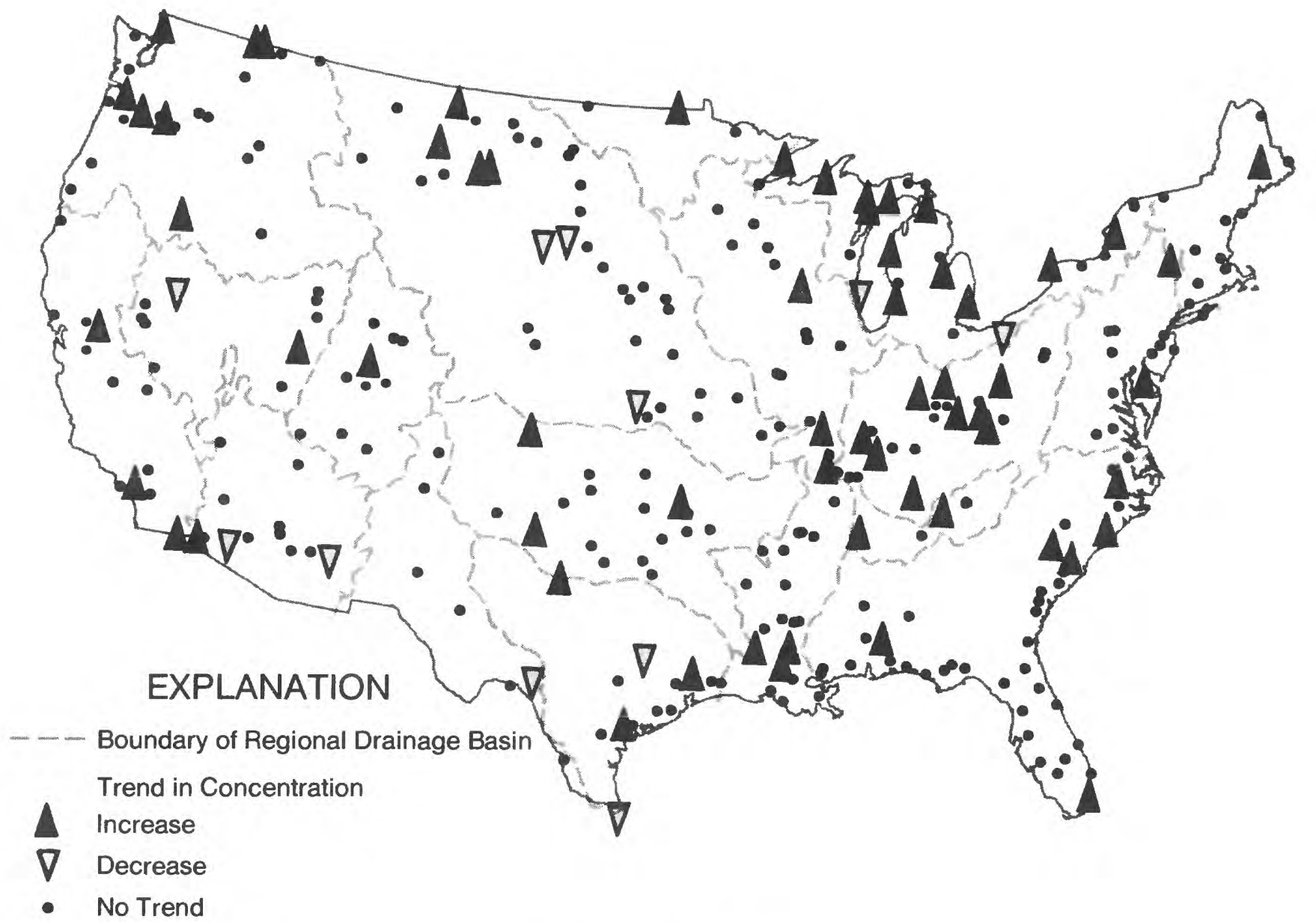

Figure 12. Trends in dissolved arsenic at NASQAN stations, 1974-81.

the level of $(p=0.016)$ and rate of decline in ( $p=0.007$ ) gasoline-lead consumption (Ethyl Corporation, 1982; Shelton and others, 1982) in the basins during the study period. Comparison of the consumption and stream-yield curves in figure 11 suggests that a lag in the response of stream-lead yield to declines in gasoline-lead consumption may account for the absence of significant trends in stream-lead concentrations in some basins. The steepest rate of decline in both stream lead and

Figure 11. Changes in mean rates of gasoline-lead consumption and stream-lead yield (dissolved) in NASQAN drainage basins. The level and rate of decrease of gasoline-lead consumption over the study period is greater among basins where stations show significant decreases in stream-lead concentration (solid lines) than in basins where stations do not show significant decreases in stream-lead concentrations (dashed lines). gasoline lead [and also in urban-air lead (U.S. Environmental Protection Agency, 1983)] occurred during 1980, and corresponded to a 31-percent drop in the lead content of leaded gasoline and a 14-percent decline in the volume of leaded-gasoline consumed (Ethyl Corporation, 1982; Shelton and others, 1982). Among basins showing significant decreases in stream-lead concentrations, stream yield of dissolved lead averaged 5 percent of gasoline-lead consumption in the basin (fig. 11).

\section{Arsenic}

Trends in dissolved arsenic (fig. 12) were predominantly up during the study period, occurring most frequently in the Great Lakes, Ohio, and Pacific Northwest basins. The relatively few 
decreases were scattered throughout the Western United States.

Evidence for the importance of anthropogenic sources of arsenic lies in the lack of association of arsenic trends with arsenic concentrations in soils and other surficial materials (Boerngen and Shacklette, 1981; Shacklette and Boerngen, 1984). Major anthropogenic sources of arsenic (Scow and others, 1982) include combustion of fossil fuels (mainly coal), herbicides, and phosphate-bearing commodities, including detergents and fertilizers. Fossil-fuel combustion, the largest source of arsenic in mass terms, introduces arsenic to the aquatic environment through atmospheric deposition of combustion products, and in runoff from fly-ash storage areas near powerplants and nonferrous smelters (Scow and others, 1982). Arsenic concentrations in precipitation (Galloway and others, 1982) range from 0.29 micrograms per liter in rural areas to 5 micrograms per liter in urban areas. Mean concentrations of dissolved arsenic at stations showing significant trends lie mostly within this range. Sedimentary evidence from Adirondack lakes indicates that increasing atmospheric deposition of arsenic has occurred since the 1950's (Heit and others, 1981; Nriagu, 1983).

There is further evidence that atmospheric deposition of arsenic is favored over terrestrial sources as a cause of the arsenic trends at NASQAN stations. Existing trace-metal-deposition measurements (Galloway and others, 1982) are too sparse to show a geographic pattern of arsenic deposition, but sulfate-deposition records provide a reasonable surrogate because of a tendency for arsenic to be transported with the smaller, sulfur-bearing particles emitted from powerplants and smelters (Natusch and others, 1974; Coles and others, 1979). The statistical association between sulfate deposition and arsenic trends is highly significant $(p=0.012)$, whereas the association between trends in arsenic and the number of powerplants and nonferrous smelters discharging wastes to streams within 160 kilometers upstream from the stations (Gianessi and Peskin, 1984) is not significant. Also, arsenic trends are not significantly related to basin herbicide use (U.S. Department of Commerce, 1974, 1977, 1982), basin fertilizer use (U.S. Department of Commerce, 1974, 1977, 1982), or municipal effluent-flow rates within 160 kilometers upstream from the stations (U.S. Environmental Protection Agency, 1979, 1982b).

\section{Cadmium}

The regional distribution of trends in dissolved cadmium (fig. 13) is very similar to that of dissolved arsenic, but trends are only moderately coincident in station-by-station comparisons. Increases occurred in the Great Lakes, Upper Mississippi, and Texas-Gulf basins. Decreases are clustered in several basins in the Great Plains States.

As with arsenic, the lack of a significant association between trends in cadmium and cadmium concentrations in surficial materials (Boerngen and Shacklette, 1981; Shacklette and Boerngen, 1984) suggests that anthropogenic sources of cadmium are of greater importance than natural sources in explaining trends. Major anthropogenic sources of cadmium to the environment (Delos, 1985) are fossil-fuel combustion, phosphate-fertilizer use, primary-metals manufacturing (ferrous and nonferrous), electroplating, and solid-waste disposal. Sedimentary evidence from Adirondack lakes indicates that increasing atmospheric deposition of cadmium has occurred since the 1950's (Galloway and Likens, 1979; Heit and others, 1981).

Chi square tests comparing cadmium trends with the geographic distributions of various anthropogenic sources of cadmium provide evidence that atmospheric deposition is of greatest importance in explaining cadmium trends. A test of association between sulfate deposition and cadmium trends is highly significant $(p=0.003)$. As with arsenic, sulfate-deposition records are a reasonable surrogate for combustion-related cadmium deposition because of the tendency for cadmium to be transported with sulfur-bearing particles (Natusch and others, 1974; Coles and others, 1979). Cadmium trends are not associated with the presence of powerplants or nonferrous smelters within 160 kilometers of the sampling stations (Gianessi and Peskin, 1984) and therefore do not appear to be related to onsite storage and disposal of fly ash. Moreover, cadmium trends are not associated with the locations of other major industrial or agricultural cadmium sources, including primary-metals manufacturing (Gianessi and Peskin, 1984), chemical manufacturing (Gianessi and Peskin, 1984), mining (metal and coal) (Gianessi and Peskin, 1984), municipal point sources (U.S. Environmental Protection Agency, 1979, 1982b), and fertilizer use (U.S. Department of Commerce, 1974, 1977, 1982).

\section{Other Trace Metals}

Significant trends in chromium, iron, manganese, mercury, selenium, and zinc were infrequent and followed no clear geographic pattern. In marked contrast to other trace metals, trends in iron, manganese, and zinc are moderately to strongly associated with trends in streamflow. 


\section{Dissolved Cadmium}

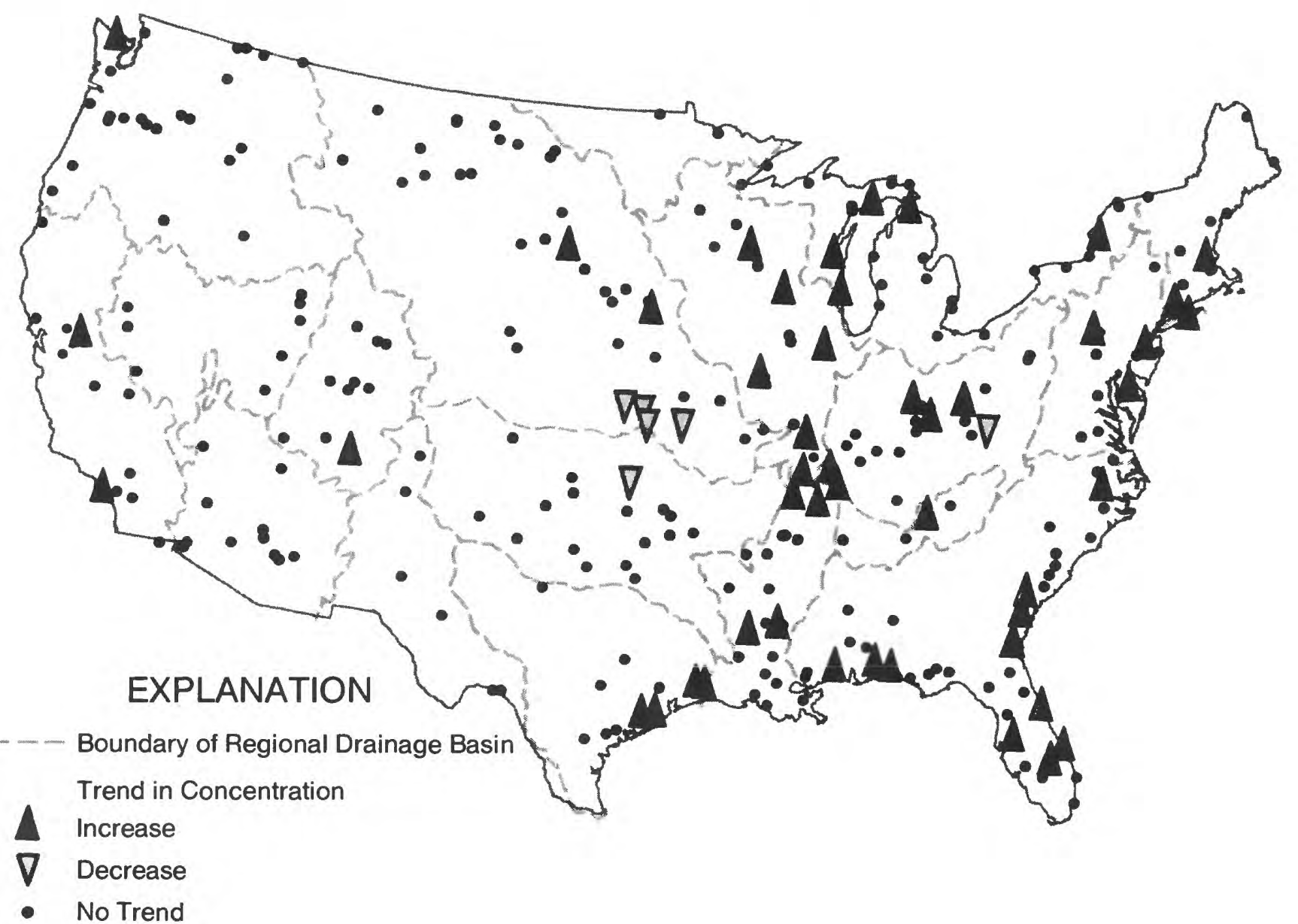

Figure 13. Trends in dissolved cadmium at NASQAN stations 1974-81.

\section{CONCLUSIONS}

The 1974-81 period was one of major change in several factors influencing water quality in the United States. More than $\$ 100$ billion was spent for water-pollution control (U.S. Environmental Protection Agency, 1984), resulting in a nearly 60-percent reduction in oxygen-demanding wastes from point sources. Increased use of fertilizers, decreased use of leaded gasoline, and large, regionally variable trends in coal production and combustion were a few of many changes in nonpoint-source influences on water quality occurring during the period. Analysis of water-quality trends at $300-400$ locations on major rivers in the United States during 1974-81 reveals evidence of both improvement and deterioration in water quality. Widespread declines in fecal bacteria and lead concentrations are examples of noteworthy improvements, while increases in arsenic, cadmium, and nitrate represent findings of some concern.

Several generalizations emerge from comparisons of trend results with ancillary data on basin conditions. Evidence for significant effects of atmospheric deposition on water quality is contained in the trend patterns for nitrate, lead, arsenic, and cadmium. The apparent major influence of atmospheric deposition on nitrate concentrations in rivers in the Eastern and Midwestern States is both unexpected and noteworthy. Atmospheric effects do not appear to include secondary effects of strongacid deposition on stream chemistry (i.e., on alkalinity, $\mathrm{pH}$, or base-cation concentrations), but alkalinities at most stations are too high to expect such secondary effects. The observed decreases in lead and increases in arsenic and cadmium are consistent with previously reported evidence of trends in deposition of those elements and, along with nitrate, 
emphasize the diversity of atmospheric influences on water quality.

Some evidence also exists for increased effects of terrestrial nonpoint sources on water quality, including effects of increased fertilizer use on nitrate concentrations and of cropland erosion on suspended-sediment concentrations. In addition, chloride increases at many locations parallel increases in the use of road salt, and sulfate trends follow regional changes in surface coal production.

Evidence of the beneficial effects of improved treatment of point-source effluents on water quality appears in observed trends in fecal bacteria and total phosphorus. The weak association between observed trends in dissolved-oxygen deficit and recorded changes in municipal biochemical oxygen demand loads suggests that detectable improvements in dissolved-oxygen conditions do not generally extend to the locations of the stations studied here. Given the bias toward high biochemical oxygen demand loads at these stations in comparison to river reaches in general, one is forced to conclude that detectable effects of improved municipal treatment on dissolved oxygen are limited to a small fraction of total river miles. Case studies do, however, provide convincing evidence of local improvements in dissolved-oxygen conditions following treatment-plant upgrading. Moreover, the ecological significance of local dissolved-oxygen improvements may be large in proportion to their spatial extent. This fact serves to illustrate the continuing need to combine network data collection with more intensive types of water-quality and biological investigations.

Some considerations for future network design arise from our analysis of NASQAN and NWQSS data. Neither network was designed to provide a randomly selected or representative sample of conditions in all river reaches in the Nation. Such a sample would probably not be desirable for most water-quality issues because of the very rural nature of the large majority of reaches. For example, median population density per square kilometer within 50 kilometers of all reaches is about 10 , and for stations in the combined network, about 20 . Despite the bias of combined network stations toward higher population density, both densities represent more rural conditions than those in which most human contact and use of water takes place. By comparison, median population density per square kilometer for individuals in the conterminous United States (within 50 kilometers of residence) is about 90 . The addition of stations closer to known sources of pollution would likely make the network less representative of nationwide condi- tions but would increase the ability to detect and investigate human influences on water quality and the effects of water quality on water use. Also, many NASQAN basins are large and, hence, heterogeneous, and the factors affecting basin water quality in them are more complex than the factors affecting smaller basins with less diverse activities. This, in turn, makes it more difficult to separate explanatory variables and to investigate associations between ambient water quality and potential sources of pollution. The addition of smaller basins more homogeneous with respect to land use, industrial activity, and pollution sources would improve the ability to investigate specific water-quality issues, including those of either a distinctly rural or urban nature.

\section{REFERENCES CITED}

Ackerman, W.C., Harmeson, R.H., and Sinclair, R.A., 1970, Some long-term trends in water quality of rivers and lakes: Transactions of the American Geophysical Union, v. 51, p. 516-522.

Agresti, A., Wackerly, D., and Boyett, J.M., 1979, Exact conditional tests for cross-classifications: Approximation of attained significance levels: Psychometrika, v. 44 , p. $75-83$.

Association of State and Interstate Water Pollution Control Administrators (ASIWPCA), 1984, America's clean water: The States' evaluation of progress: 1972-1982; Washington, D.C. 17 p.

1985, America's clean water: The States' nonpoint source assessment, 1985, Washington, D.C., 25 p.

Biesecker, J.E., and Leifeste, D.K., 1975, Water quality of hydrologic bench marks: U.S. Geological Survey Circular 460-E, 21 p.

Boerngen, J.G., and Shacklette, H.T., 1981, Chemical analyses of soils and other surficial materials of the conterminous U.S., U.S. Geological Survey Open-File Report 81-197, 145 p.

Briggs, J.C., 1978, Nationwide surface water quality monitoring networks of the U.S. Geological Survey: American Water Resources Association Symposium, San Francisco, June 12-14, 1978, Proceedings, p. 49-57.

Briggs, J.C., and Ficke, J.F., 1977, Quality of rivers of the United States, 1975 water year-Based on the National Stream Quality Accounting Network (NASQAN): U.S. Geological Survey Open-File Report 78-200, $474 \mathrm{p}$.

Cantor, A.B., 1979, A computer algorithm for testing significance in $\mathrm{M} \times \mathrm{K}$ contingency tables: Proceedings of the Statistical Computing Section: Washington, D.C., American Statistical Association, p. 220-221.

Coles, D.G., Ragaini, R.C., Ondov, J.M., Fisher, G.L., Silberman, D., and Prentice, B.A., 1979, Chemical studies of stack fly ash from a coal-fired power plant: Environmental Science Technology, v. 13, p. 455-459.

Congressional Budget Office, 1984, The budget of the Environmental Protection Agency: An overview of selected proposals for 1985: Washington, D.C., 86 p. 
Conover, W.J., 1980, Practical nonparametric statistics: New York, Wiley and Sons, p. 158-160, 191.

Conservation Foundation, 1984, State of the environment: An assessment at mid-decade: Washington, D.C., 586 p.

Council on Environmental Quality, 1981, Environmental trends: Washington, D.C., p. 237-265.

-1982, Environmental quality 1982 (13th annual report of the Council on Environmental Quality): Washington, D.C., p. 36-43.

Delos, C.G., 1985, Cadmium contamination of the environment: An assessment of nationwide risks: Washington, D.C., U.S. Environmental Protection Agency. [EPA-440/4-85-023]

DeWald, T., Horn, R., Montalbano, A., Manning, L., Taylor, P., and Greenspun, R., 1985, STORET reach retrieval documentation: Washington, D.C., U.S. Environmental Protection Agency, 54 p.

Driscoll, C.T., and Likens, G.E., 1982, Hydrogen ion budget of an aggrading forested ecosystem: Tellus, v. 34, p. 283-292.

Edwards, H.W., and Wheat, H.G., 1978, Seasonal trends in Denver atmospheric lead concentrations: Environmental Science Technology, v. 12, p. 687-692.

Ethyl Corporation, 1982, Yearly report of gasoline sales by State: Houston, Texas, $16 \mathrm{p}$.

Federal Register, 1976 , v. 41 , p. 11,458.

Fienberg, S.E., 1980, The analysis of cross-classified categorical data: Cambridge, Mass.: MIT Press, p. 15.

Galloway, J.N., and Likens, G.E., 1979, Atmospheric enhancement of metal deposition in Adirondack lake sediments: Limnology and Oceanography, v. 24, p. 427-433.

Galloway, J.N., Thornton, J.D., Norton, S.A., Valchok, H.L., and McLean, R.A.N., 1982, Trace metals in atmospheric deposition: A review and assessment: Atmospheric Environment, v. 16, p. 1677-1700.

Gianessi, L.P., and Peskin, H.M., 1981, Analysis of national water pollution control policies, 1. A national network model: Water Resources Research, v. 17 , p. $796-821$.

1984, An overview of the RFF Environmental Data Inventory: Methods, sources, and preliminary results: Resources for the Future, v. 1, $111 \mathrm{p}$.

Gibson, J.H., and Baker, C.V., 1982, 1980-1981 wet deposition measurements: Fort Collins, Colorado State University, National Atmospheric Deposition Program, $25 \mathrm{p}$.

Gilliom, R.J., Alexander, R.B., and Smith, R.A., 1985, Pesticides in the Nation's rivers, 1975-1980, and implications for future monitoring: U.S. Geological Survey Water-Supply Paper 2271, 26 p.

Gschwandtner, G., Gschwandtner, K.C., and Eldridge, K., 1985, Historic emissions of sulfur and nitrogen in the U.S. from 1900 to 1980: Washington, D.C., U.S. Environmental Protection Agency. [EPA-600/7-85-009a]

Guy, H.P., and Norman, V.W., 1970, Field methods for measurement of fluvial sediment: U.S. Geological Survey Techniques of Water-Resources Investigations, Book 3, Chapter C2, 59 p.
Haeni, F.P., 1983, Sediment deposition in the Columbia and lower Cowlitz Rivers, Washington-Oregon, caused by the May 18, 1980, eruption of Mount St. Helens: U.S. Geological Survey Circular 850-K, 21 p.

Hartig, J.H., and Horvath, F.J., 1982, A preliminary assessment of Michigan's phosphorus detergent ban: Journal of Water Pollution Control Federation, v. 54, p. 193.

Heit, M., Tan, Y., Klusek, C., and Burke, J.C., 1981, Anthropogenic trace elements and polycyclic aromatic hydrocarbon levels in sediment cores from two lakes in the Adirondack Acid Lake Region: Water, Air and Soil Pollution, v. 15, p. 441-464.

Helsel, D.R., 1983, Mine drainage and rock type influences on eastern Ohio stream water quality: Water Resources Bulletin, v. 19, p. 881-887.

Hirsch, R.M., Slack, J.R., and Smith, R.A., 1982, Techniques of trend analysis for monthly water quality data: Water Resources Research, v. 18, p. 107-121.

Jonez, A.R., 1984, Controlling salinity in the Colorado River Basin, the arid west, in French, R.H., ed., Salinity in watercourses and reservoirs: Boston, Mass.: Butterworth, p. 337-347.

Judy, R.D., Jr., Seeley, P.N., Murray, T.M., Svirsky, S.C., Whitworth, M.R., and Ischinger, L.S., 1984, 1982 national fisheries survey, Volume I, Technical report: Initial findings: Washington, D.C., Fish and Wildlife Service, 140 p. [FWS-84/06]

Kramer, J.R., Andren, A.W., Smith, R.A., Johnson, A.H., Alexander, R.B., and Oehlert, G., 1986, Streams and lakes, in National Research Council, Committee on Monitoring and Assessment of Trends in Acid Deposition, Acid deposition: Long-term trends: Washington, D.C., National Academy Press, p. 231-299.

Langbein, W.B., and Durum, W.H., 1967, The aeration capacity of streams: U.S. Geological Survey Circular 542, 6 p.

Leo, W.M., Thomann, R.V., and Gallagher, T.W., 1984, Before and after case studies: Comparisons of water quality following municipal treatment plant improvements: Washington, D.C., U.S. Environmental Protection Agency. [EPA-430/9-007]

Leopold, L.B., and Maddock, Thomas, Jr., 1953, The hydraulic geometry of stream channels and some physiographic implications: U.S. Geological Survey Professional Paper 252, 57 p.

Likens, G.E., 1983, A priority for ecological research: Bulletin of the Ecological Society of America, v. 64, p. 234-243.

Meade, R.H., and Parker, R.S., 1985, Sediment in rivers of the United States, in National water summary 1984: U.S. Geological Survey Water-Supply Paper 2275, p. 49-60.

Mining Informational Services, 1976, 1983, Keystone coal industry manual: New York, McGraw-Hill.

National Research Council, 1983, Acid deposition: Atmospheric processes in Eastern North America: Washington, D.C., NAS Press, 375 p.

Natusch, D.F.S., Wallace, J.R., and Evans, C.A., Jr., 1974, 
Toxic trace elements: Preferential concentration in respirable particles: Science, v. 183, p. 202-204.

Nriagu, J.O., 1983, Arsenic enrichment in lakes near the smelters at Sudbury, Ontario: Geochimica et Cosmochimica Acta, v. 47, p. 1523-1526.

Peters, N.E., 1984, Evaluation of environmental factors affecting yields of major dissolved ions of streams in the United States: U.S. Geological Survey WaterSupply Paper 2228, 39 p.

Peters, N.E., and Turk, J.T., 1981, Increases in sodium and chloride in the Mohawk River, New York, from the 1950's to the 1970's attributed to road salt: Water Resources Bulletin, v. 17, p. 586-598.

Rockwell, D.C., Marian, C.V., Palmer, M.F., DeVault, D.S., and Bowden, R.J., 1980, Environmental trends in Lake Michigan, in Loehr, R.C., Martin, C.S., and Rast, W., eds., Phosphorus management strategies for the Great Lakes: Ann Arbor, Mich., Ann Arbor Science Publishing Co., p. 91-132.

Salt Institute, 1975, 1980, Survey of salt, calcium chloride and abrasive use in the United States and Canada: Alexandria, Va., 18 p.

Scott, W.S., 1980, Road salt movement in two Toronto streams: Journal of the Environmental Engineering Division, American Society of Civil Engineers, v. 106, p. 547-560.

Scow, K., Byrne, M., Goyer, M., Nelken, L., Perwak, J., Wood, M., and Young, S., 1982, An exposure and risk assessment for arsenic: Washington, D.C., U.S. Environmental Protection Agency, $247 \mathrm{p}$.

Shacklette, H.T., and Boerngen, J.G., 1984, Elemental concentrations in soils and other surficial materials of the conterminous U.S.: U.S. Geological Survey Professional Paper 1270, $105 \mathrm{p}$.

Shelton, E.M., Whisman, M.L., and Woodward, P.W., 1982, Trends in motor gasolines: 1942-1981: Bartlesville, Okla., Department of Energy, Bartlesville Energy Technology Center, 27 p. [DOE/BETC/RI-82/4]

Skougstad, M.W., Fishman, M.J., Friedman, L.C., Erdmann, D.E., and Duncan, S.S., eds., 1979, Methods for determination of inorganic substances in water and fluvial sediments: U.S. Geological Survey Techniques of Water-Resources Investigations, Book 5, Chapter A1, $626 \mathrm{p}$.

Smith, R.A., and Alexander, R.B., 1983a, Evidence for acid-precipitation-induced trends in stream chemistry at hydrologic bench-mark stations: U.S. Geological Survey Circular 910, 12 p.

1983b, A statistical summary of data from the U.S. Geological Survey's National Water Quality Networks: U.S. Geological Survey Open-File Report 83-533, 30 p.

1984, Trends in concentrations of dissolved solids, suspended sediment, phosphorus, and inorganic nitrogen at U.S. Geological Survey National Stream Quality Accounting Network stations, in National water summary 1984: U.S. Geological Survey Water-Supply Paper 2275, p. 66-73.
1986, Correlations between stream sulphate and regional $\mathrm{SO}_{2}$ emissions: Nature, v. 322, p. 722-744.

Smith, R.A., Hirsch, R.M., and Slack, J.R., 1982, A study of trends in total phosphorus measurements at NASQAN stations: U.S. Geological Survey WaterSupply Paper $2190,34 \mathrm{p}$.

Stumm, W., and Morgan, J.J., 1981, Aquatic chemistry: New York, Wiley and Sons, p. 193-195.

Taylor, P., 1983, Final report on the Industrial Facility Discharge File: Washington, D.C., U.S. Environmental Protection Agency, Office of Water, Regulations, and Standards.

Thomann, R.V., 1972, Systems analysis and water quality management: New York, McGraw-Hill, $286 \mathrm{p}$.

Trimble, S.W., 1981, Changes in sediment storage in the Coon Creek Basin, Driftless Area, Wisconsin, 1853 to 1975: Science, v. 214, p. 181-182.

Turner, R.S., Johnson, A.H., Wang, D., 1985, Biogeochemistry of lead in McDonalds Branch Watershed, New Jersey Pine Barrens: Journal of Environmental Quality, v. 14 , p. 305-314.

U.S. Department of Agriculture, 1982, National resources inventory: A guide for users of the 1982 NRI data files: Washington, D.C., 36 p.

1983, Handbook of agricultural charts, Agricultural Handbook no. 619: Washington, D.C.

U.S. Department of Commerce, Census of Agriculture, 1974, 1977, 1982, Final county file, Technical documentation: Washington, D.C.

Census of Population and Housing, 1983, 1980: Master Area Reference File (MARF) 2 [machine readable datafile], Washington, D.C., Bureau of Census.

1970, 1970: Master Enumeration District Area(MEDList) [machine readable datafile], Washington, D.C., Bureau of Census.

U.S. Department of the Interior, 1983, Quality of water: Colorado River Basin, Progress Report 11: Washington, D.C.,

U.S. Environmental Protection Agency, 1976, Basic water monitoring program: Washington, D.C., 51 p. [EPA-440/9-76-025]

1977, National water quality inventory: 1977 report to Congress: Washington, D.C. [EPA-440/4-78-001] $-1979,1978$ needs survey: Washington, D.C., 84 p. [EPA-430/9-79-001]

1980, National accomplishments in pollution control: 1970-1980: Washington, D.C., p. 9-51.

1982a, National water quality inventory: 1982 report to Congress: Washington, D.C., 63 p. [EPA-440/2-84-006]

1982 b, 1982 needs survey: Washington, D.C., 85 p. [EPA-430/9-82-009]

1983, National air quality and emissions trends report, 1981: Washington, D.C., p. 42-45. [EPA-450/4-83- 011]

1984, The cost of clean air and water report to Congress 1984: Washington, D.C., 21 p. [EPA-230/05-84-008]

U.S. Geological Survey, 1983, National water summary 
1983-Hydrologic events and issues: U.S. Geological Survey Water-Supply Paper 2250, p. 45-51.

Williams, G.P., and Wolman, M.G., 1984, Downstream effects of dams on alluvial rivers: U.S. Geological Survey Professional Paper 1286, 83 p.

Wolman, M.G., 1971, The nation's rivers: Science, v. 174, p. 905-918. 